\title{
Biomedicine and Diseases: Review
}

\section{Neurofilament proteins in neurodegenerative diseases}

\author{
Q. Liu ${ }^{\text {a, } * \text { F. Xie }}$, S. L. Siedlak ${ }^{\text {a }}$ A. Nunomura ${ }^{c}$, K. Honda ${ }^{\text {a }}$ P. I. Moreira ${ }^{\text {a,d }}$, X. Zhua, M. A. Smith ${ }^{\text {a }}$ \\ and G. Perry $\mathrm{a}$, * \\ ${ }^{a}$ Institute of Pathology, Case Western Reserve University, 2085 Adelbert Road, Cleveland, Ohio 44106 (USA), \\ Fax:+1 216368 8964, e-mail: quan.liu@case.edu or george.perry@case.edu \\ ${ }^{\mathrm{b}}$ Department of Pharmacology, Case Western Reserve University, Cleveland, Ohio 44106 (USA) \\ ${ }^{c}$ Department of Psychiatry and Neurology, Asahikawa Medical College, Asahikawa 078-8510 (Japan) \\ ${ }^{\mathrm{d}}$ Center for Neuroscience and Cell Biology of Coimbra, University of Coimbra, 3004-517 Coimbra (Portugal)
}

Received 22 June 2004; received after revision 4 August 2004; accepted 19 August 2004

\begin{abstract}
The function of neurofilaments, the major component in large myelinated neurons, is not well understood even though they were discovered as structures over 100 years ago. Recent studies have suggested that neurofilaments are closely related to many neurodegenerative diseases, such as amyotrophic lateral sclerosis, Parkinson
\end{abstract}

disease Alzheimer disease, and diabetes. Using in vitro assays, cultures and transgenic mice, these studies provided new insights into neurofilament function. The function of each subunit, the relationship of neurofilaments with other cytoskeletal elements and their clinical significance are topics of increasing attention.

Key words. Alzheimer disease; amyotrophic lateral sclerosis; cytoskeleton; glycosylation; neurofilament proteins; phosphorylation; transgenic mice; Parkinson disease.

\section{Introduction}

Neurofilaments (NFs) are intermediate filaments of neurons that are considered to add rigidity, tensile strength and possibly intracellular transport guidance to axons and dendrites [1]. Exclusively expressed in neurons, NFs are members of the cytoskeleton proteins that act together to form and maintain cell shape and facilitate the transport of particles and organelles within the cytoplasm.

Based on differences in diameter and protein components, cytoskeletal polymers are classified into three groups: microtubules (MTs) $(\sim 24 \mathrm{~nm})$, microfilaments (MFs) $(\sim 6-8 \mathrm{~nm})$ and intermediate filaments (IFs) $(\sim 10 \mathrm{~nm})$. MTs, which are predominatly composed of tubulin, are responsible for maintaining cell shape, organelle and vesicle movement, and the formation of spindle fibers during mitosis. MFs, which are composed predominantly of actin, are responsible for cellular movement, muscle

\footnotetext{
* Corresponding authors.
}

contraction, mechanical strength and cytokinesis. IFs are composed of different proteins and are prominent in cells that withstand mechanical stress. Moreover, IFs are the most insoluble components of the cells. In contrast to the similarity in polymer composition of MTs and MFs in all tissues, IF polymers differ in different tissues and different cells. Based on molecular structural homology, five types of IFs have been identified, and NFs belongs to type IV IFs (table 1).

In this review, current knowledge about NF history, general properties, expression, assembly, transport, posttranslational modification, degradation, functions, transgenic mouse models, related diseases and clinical implications will be summarized

\section{History}

As early as the 1830 s, neuronal networks had already been described $[2,3]$. The discovery of the silver staining method in the late 19th century resulted in a clear vision 
Table 1. Types of IFs. IFs include five defined types and other undefined types. Their molecular weights are varied, and they are found in different cell types. Neurofilament subunits belong to type IV IFs.

\begin{tabular}{|c|c|c|c|}
\hline Type & Name & Molecular weight & Cell \\
\hline I & acid keratins & $40-60 \mathrm{kDa}$ & epithelial \\
\hline II & basic keratins & $50-70 \mathrm{kDa}$ & epithelial \\
\hline III & $\begin{array}{l}\text { desmin } \\
\text { GFAP } \\
\text { peripherin/vimentin }\end{array}$ & $50-70 \mathrm{kDa}$ & $\begin{array}{l}\text { muscle } \\
\text { astroglia } \\
\text { mesenchymal, tissue cultured cells }\end{array}$ \\
\hline IV & $\begin{array}{l}\text { NF-L, NF-M, NF-H } \\
\alpha \text {-internexin } \\
\text { nestin }\end{array}$ & $50-200 \mathrm{kDa}$ & $\begin{array}{l}\text { neuronal } \\
\text { immature neuronal } \\
\text { CNS stem cells }\end{array}$ \\
\hline V & nuclear lamins & $60-70 \mathrm{kDa}$ & most other undefined types \\
\hline
\end{tabular}

of NFs [4, 5], which also led to the characterization of neurofibrillary tangles and senile plaques by Alois Alzheimer [6]. With the development of electron microscopy after 1931 (Max Knoll and Ernst Ruska in Germany), the molecular structures of NFs were further defined as filaments $\sim 10 \mathrm{~nm}$ in diameter and present exclusively in neuronal cells. For a long time, it was known that NFs are involved in several neuronal diseases, and in the past decade, NFs have been linked to more human diseases, which will be discussed here. With the development of specific antibodies, transgenic animal models and molecular genetic methodologies, studies of NFs advanced to the molecular level.

\section{General properties}

Together with peripherin, $\alpha$-internexin and nestin, NFs belong to type IV IFs and share common sequence structures (table 1). A central $\alpha$-helical rod domain of about
310 amino acids is flanked by a globular N-terminal region and non $-\alpha$-helical carboxy-terminal side-arm domains. The central rod domains, including regions $1 \mathrm{a}$, $1 \mathrm{~b}$, and 2 , contain highly conserved motifs and every seventh residue is hydrophobic, which facilitates the formation of $\alpha$-helical coiled-coil parallel homodimers or heterodimers. A linker region aligns the hydrophobic residues. These properties are characteristic of the IFs and are essential for their proper assembly (fig. 1).

NFs are composed of three subunits, and these subunits are defined by their molecular weight: NF-L (light), NF-M (medium) and NF-H (heavy), which are $60 \mathrm{kDa}$, $100 \mathrm{kDa}$ and $110 \mathrm{kDa}$, respectively, as predicted from the DNA sequences [7]. These subunits exhibit higher molecular weights on SDS-polyacrylamide gel electrophoresis (PAGE): $68 \mathrm{kDa}, 160 \mathrm{kDa}$ and $205 \mathrm{kDa}$, respectively, because of the enriched negatively charged amino acids (glutamic acid) in their sequences and post-translational modifications such as phosphorylation and glycosylation $[7,8]$. NFs constitute the most abundant struc-

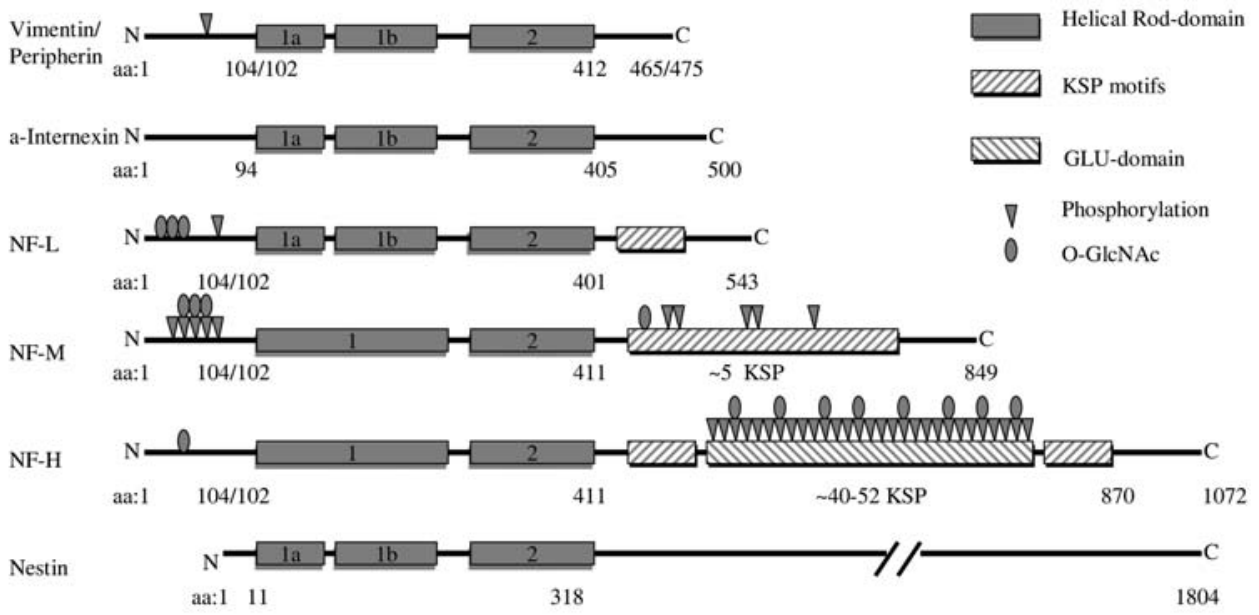

Figure 1. Comparison of the structures of NF subunits and other type IV filaments. The NF subunits and other type IV IFs all include $\alpha$ helical rod domain and are varied in N- and C-termini. A unique character of NF-M and NF-H is that their C-termini have multiple KSP repeats which are heavily phosphorylated. Also shown here, are posttranslational modifications, including phosphorylation and glycosylation on NF subunits (summarized from $[7,8,11]$ ). 
tures in large myelinated neurons, and can account for $13 \%$ of total proteins and $54 \%$ of the Triton-insoluble proteins in some neurons [9, 10]. More detailed description of all IF structures is recorded in several reviews $[7,11,12]$.

\section{Expression}

The three NF subunits are expressed at distinct stages of vertebrate development, triggered by neuron differentiation [13-15]. Initially, NF-L is expressed at the beginning of neuronal differentiation and overlaps with the expression of $\alpha$-internexin and peripherin $[14,16]$. NF-M is expressed shortly after with the emergence of neurite formation, whereas NF-H is expressed later when axonal radial growth is required for nervous system maturation $[14,16]$.

The genes coding for human NFs include NEFL gene (NF-L protein), NEFM gene (NF-M protein), and NEFH gene (NF-H protein). NEFL and NEFM genes are closely located, at chromosome 8, 8p21 [17, 18]; NEFH gene is at chromosome 22, 22q12.2 [19]. Expression of messenger RNAs (mRNAs) of NF subunits is consistent with their protein levels in cultured neuroblastoma cells, and NF-L and NF-M mRNAs are expressed several days before the appearance of NF-H mRNA in these cells [20]. It appears that the NF-L and NF-M genes are coordinately regulated, while the NF-H gene is expressed independently later.

\section{Assembly}

NF assembly is not clearly understood yet, though in vivo studies have demonstrated that NFs are obligate heteropolymers requiring NF-L to form a proper polymer with either NF-M or NF-H [21, 22]. NF formation is believed to start with the dimerization of NF-L with either NF-M or NF-H subunits. The highly conserved rod domains of the NF subunits are coiled together in a head-to-tail fashion to form a dimer. Two coiled dimers overlap with each other in an anti-parallel, half-staggered manner, forming the tetramers. Finally, eight tetramers are packed laterally and longitudinally together in a helical array, forming a ropelike $10-\mathrm{nm}$ filament [11, 23-25]. In the cross section of NF, there are $\sim 32$ molecules, though the number may change in different stages or conditions [26]. Theoretically, before the synthesis of NF-H, NFs are only composed of NF-L and NF-M [27]. The C-termini of NF-M and NF-H are not in the coils, but they form the side arms of the NFs [28] (fig. 2).

NF-L is essential for the precise assembly of NFs [21, 22, 29]. NF-M participates in the formation of cross-bridges,

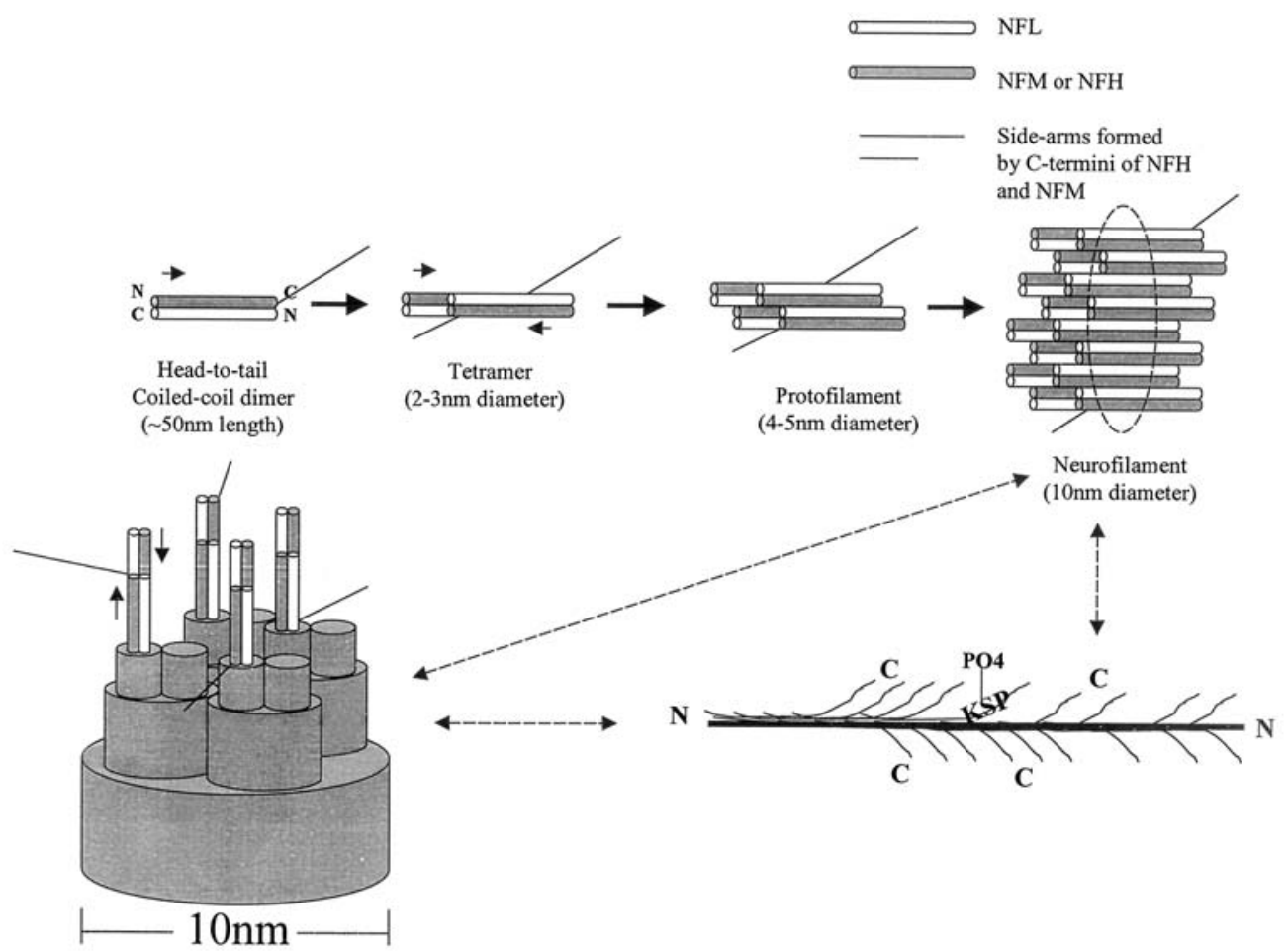

Figure 2. Schematic model of NF assembly. In the NF assembly process, two NF subunits (NF-L, and either NF-H or NF-M) form headto-tail coiled-coil dimers, anti-parallel half-staggered tetramers, protofilaments, and 10-nm NFs. There are $\sim 32$ molecules in the crosssection, and hyperphosphorylated side arms formed by the C-termini of NF-H and NF-M stick out of the stem of the filament. 
stabilization of the filament network and longitudinal extension [30-33]. NF-H also contributes to the formation of cross-bridges and may interact with microtubules/microfilaments and other cytoskeletal elements [32-34]. However, recent studies showed NF-H side arms are not critical for radial growth of the axons $[12,35]$. NF-M and NF-H by themselves do not form filaments in vivo $[21,22,29,36]$, while NF-L can form homopolymers in vitro $[37,38]$ and in cells transfected with NF-L [39], but not in mice [33]. Although NFs are obligate heteropolymers in vivo in rodents, this may not be the case in humans [39].

In contrast to NF subunits, $\alpha$-internexin and peripherin self-assemble into homopolymers and co-assemble with NF subunits [40-42]. Many central nervous system (CNS) neurons also contain varying levels of $\alpha$-internexin, a type IV IF subunit [43] expressed abundantly in embryonic neurons but at lower levels postnatally [44, 45]. Although $\alpha$-internexin co-localizes with NFs and forms filaments with each of the triplet proteins in vivo [21], the composition of the filaments is still not known in vivo. Peripherin, a type III IF, is expressed in lower motor, autonomic, and sensory neurons and also co-assembles with the NF subunits [41, 42].

\section{Transport}

After their synthesis in the perikarya, neurofilament proteins (NFPs) are quickly translocated into the axons and assemble into filamentous structures. In radioisotopic labeling studies, neurofilament proteins move at a rate of $0.2-1 \mathrm{~mm} /$ day in the axon with the slow components, whereas other organelles such as membrane vesicles can move at the much faster rate of $200-400 \mathrm{~mm} /$ day [46].

The mechanism by which IF proteins are transported has been a topic of debate for many years due to the lack of techniques in determining the form in which these proteins are transported. The polymer hypothesis suggests that NF subunits are assembled and transported mainly as polymeric structures $[47,48]$, whereas the subunit hypothesis argues that the NF proteins are transported down the axon as individual subunits or small oligomers [49-52]. Photobleaching experiments with fluorescent-tagged proteins support the subunit hypothesis, in which the bleached axonal segment remained stationary with gradual recovery of its fluorescence without any obvious directionality [53]. Recently, using green fluorescent protein (GFP)tagged NF subunits and live cell imaging, two research groups found a fast transport of NF polymers down the axon at a rate up to $2 \mathrm{~mm} / \mathrm{s}[54,55]$ which was interrupted by prolonged pauses and resulted in a net slow velocity. Therefore, the current understanding of NF transport is that they are transported bi-directionally in the axon along microtubules through common motors such as dynein and kinesin. The average slow rate of NF movement is because NF structures spend most of their time ( $>99 \%)$ pausing in the axon. The pauses might be the result of a lack of transient interactions between motors and NF structures. Consistent with this model, the kinesin motor was found to co-localize with the motile NF pool in the squid giant axon [56]. In addition, phosphorylation of NFPs (mainly on NF-H) resulted in their dissociation from the kinesin motor, thereby decreasing their transport speed [57].

\section{Posttranslational modifications}

Two major posttranslational modifications are involved in the formation and functions of NFs, phosphorylation and glycosylation.

\section{Phosphorylation}

NFP phosphorylation is topographically regulated within neurons. Recent studies show that phosphorylation of the NF subunits plays a critical role in regulation of filament translocation, formation and function. It is also involved in the pathogenesis of some related neurodegenerative diseases.

Almost all ( $>99 \%)$ of the assembled NFs in myelinated internodal regions are known to be stoichiometrically phosphorylated in the Lys-Ser-Pro (KSP) repeat domains [58]. In contrast, the KSP repeats of NFPs in cell bodies, dendrites and nodes of Ranvier are less phosphorylated. The unphosphorylated NFs only account for $\sim 1 \%$ of NFs in the neuron as judged by NF density and the relative volumes of the respective compartments [58-60].

Although other Ser/Thr motifs are also phosphorylated, most phosphorylation sites are in KSP motifs of the tail domains of NF-M and NF-H. It is consistent with the studies done by Jaffe et al. [61] showing that 33 out of 38 phosphorylation sites of NF-H C-terminus are at KSP motifs. Normally NF-M and NF-H undergo posttranslational hyperphosphorylation upon entry into the axons. The phosphorylation of NF-M occurs at embryonic day 13 (E13) in mouse spinal cord neurons, and the NF-M level and its phosphorylation demonstrate a polarized character in the growing axons: a proximal-distal gradient with most intense expression in axons of peripheral nerves, and little or no detection in perikarya and dendrites [62-65]. NF-M and NF-L levels reach adult values at E15 when a low level of a mixture of non-phosphorylated and phosphorylated NF-H is first detected in brain and spinal cord. Phospho-NF levels are increased in brain and spinal cord axons after E17 and are displayed in a gradient fashion along the axon, proximally to distally, as if responding to signals from terminals $[15,16]$. Myelination also promotes NFP phosphorylation and radial growth of axons, while demyelination of motor neurons causes loss of 


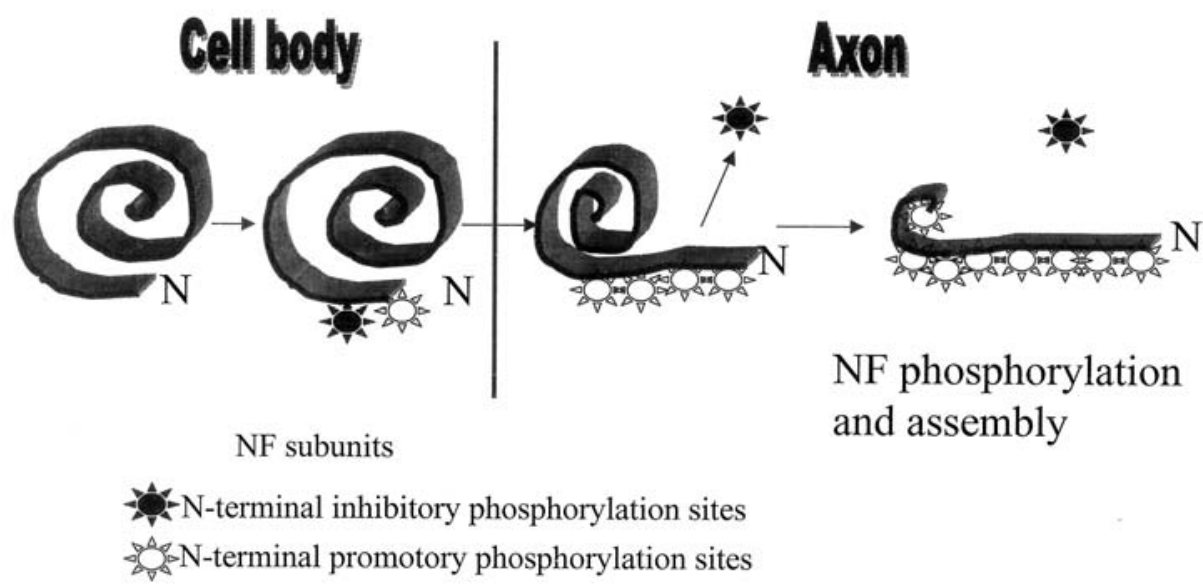

Figure 3. Regulatory functions of NF phosphorylation. N-terminal phosphorylation has both inhibitory and promotional effects for C-terminal phosphorylation in NFs, and N-terminal phosphorylation can also control NF translocation and assembly in axons.

phosphorylation on NF-M and NF-H [59]. This may be due to regulation of relevant phosphatases and kinases.

In vivo phosphorylation of NFPs in axons is a slow process [66]. The explanation of this includes the slow transport of NF proteins into the axon, delayed activation of local kinases or more possibly the inaccessibility of phosphate acceptor sites because of a 'closed' conformation of the assembled polymer. The topologically sequential phosphorylation may be due to the sequential opening of the next accessible phosphorylation site after the prephosphorylation of the other sites (fig. 3).

NFP phosphorylation plays multiple roles; its major function is believed to be the regulation of axonal radial growth. Extensive phosphorylation of KSP repeats in the tail domain of NF-M and NF-H occurs primarily in axons $[15,62,67]$. This results in side-arm formation, increased interneurofilament spacing, radial growth of axons and increased conduction velocity $[36,59,68]$. Phosphorylation of KSP motifs triggered by a Schwann cell signal has been proposed as a key determinant of local control of $\mathrm{NF}$ accumulation, interfilament spacing and radial growth of myelinated axons $[59,64,68-70]$. Recent studies using NF-H null mice, or mice transfected with a NF-H tailless mutant, suggest that neither NF-H nor its phosphorylated tail is essential for determining neuronal caliber [71, 72]. These studies, together with those using NF-M knockout mice $[31,32,73]$, indicate that NF-M plays a more profound role in regulating the axonal diameter. Moreover, alternation of NF-M and NF-H tail domain phosphorylation is associated with the pathology seen in neurodegenerative disorders such as amyotrophic lateral sclerosis (ALS) and Alzheimer disease (AD), in which tail domain phosphorylation and NF accumulation occur abnormally in perikarya [74-77].

Recent studies show that phosphorylation also plays a critical role in inhibiting NF assembly in the perikaryon, which explains why NFPs only form filaments in axons
$[15,62,67]$. N-terminal head domain phosphorylation by protein kinase A (PKA) at Ser ${ }^{55}$ in NF-L or Ser ${ }^{46}$ in NF-M inhibits assembly of NF subunits into a heteropolymer in vitro and in vivo [78-82]. Consistent with these studies, phosphorylation/dephosphorylation of $\mathrm{Ser}^{55}$ and $\mathrm{Ser}^{57}$ in NF-L regulates NF assembly and disassembly $[83,84]$. Prevention of NF-L Ser ${ }^{55}$ dephosphorylation through a Ser-to-Asp mutation, mimicking permanent phosphorylation, resulted in pathological accumulation of NF aggregates in brain neuronal cell bodies [84]. These studies suggested that the transient head domain phosphorylation in cell bodies elaborately regulates NFP polymerization and filament formation in perikarya [22, 85]. Moreover, dephosphorylation of these sites is prerequisite for NFP assembly in axons.

In addition to the axonal assembly, phosphorylation of head domain sites of NF-M also regulates phosphorylation of the tail domain KSP repeats in perikarya and axons. Zheng et al. [86] found that NF-M head domain phosphorylation by PKA decreases Erk1/2 kinase activated tail domain phosphorylation in vitro and in vivo, and mutant NF-M (Ser ${ }^{1,23,46}$ to Ala) diminished this regulation in transfected NIH3T3 cells. These findings are consistent with the hypothesis that transient phosphorylation of NF-M head domains inhibits phosphorylation of tail domains and poses a new mechanism for topographic regulation of NFP phosphorylation in neurons. So transient phosphorylation of head domain motifs of NF-L and NF-M by PKA and PKC in cell bodies can prevent NF assembly and C-terminal phosphorylation in perikarya $[22,78,80,81,85]$, protecting the neuron from abnormal accumulation of phosphorylated NFP aggregates in cell bodies. In fact, few NFs are seen in cell bodies, and only small oligomers can be detected, which suggests that consequential NF assembly is restricted to axons during transport [87]. If this tight topographic regulation is altered by a variety of exogenous factors, then abnormal 
NF assembly and tail domain phosphorylation would be induced in cell bodies with severe pathological consequences. As we know, in neurodegenerative diseases such as ALS and AD, abnormally phosphorylated NFPs in the cell bodies are the hallmark of the disease [12].

Phosphorylation of NFs may also slow down NF transport within axon. It has been proposed that the heavily phosphorylated NF-H subunit detaches from the transport carrier and resides in the axon for months, whereas less phosphorylated subunits are transported at normal slow axonal transport rates and have a short residence time in the axon $[88,89]$. Consistent with this hypothesis, studies of complete deletion of NF-H, NF-M or both increase the rate of transport of the remaining NF subunits in mouse sciatic nerves [31-33, 90]. Moreover, in cultured optic nerve axons, hypophosphorylated NF subunits have been interpreted to undergo axonal transport more rapidly than subunits more extensively phosphorylated at their tail domains [91], and the C-terminal phosphorylation of the NF-H subunit correlates with decreased NF axonal transport velocity [92, 93]. But Rao et al. [35] constructed NF-H tailless mice by an embryonic stem cell mediated gene knock-in approach and showed the NF-H tail is important neither for the axonal diameter nor the transport rate. Ackerley et al. [94] argued with these results by analyzing movement of GFP-tagged phosphorylation mutants of NF-H in neurons, which supports a role for NF-H side-arm phosphorylation as a regulator of NF transport. Most of the studies supports phosphorylation of NF side arms regulating NF transport rates $[69,93$, $95,96]$.

\section{Glycosylation}

In addition to phosphorylation, NFs are also modified posttranslationally with O-linked $\mathrm{N}$-acetylglucosamine $(O$-GlcNAc) on serine and threonine residues [8], which is the simplest protein modification with sugars [97]. Initially discovered from murine lymphocytes [98], this modification has been found in all compartments of eukaryotic cells [99]. The O-GlcNAc modification $(O-$ GlcNAcylation) is highly abundant and dynamic, similar to phosphorylation [100-106].

NF-H, NF-M and NF-L are modified by $O$-GlcNAc in vivo to stoichiometries of at least $0.3,0.15$ and $0.1 \mathrm{~mol}$ GlcNAc/mol of protein at both termini [107] (fig. 1). Although the stoichiometry of $O$-GlcNAcylation on isolated NFPs is very low compared with phosphorylation, it seems likely that only a subset of NF subunits is modified by $O$-GlcNAc, and the stoichiometry in those subunits is probably much higher. It is worth mentioning that this $O$-GlcNAcylation most likely is a consensus of the $\mathrm{PX}_{0-4}(\mathrm{~S} / \mathrm{T})$ motif ( $\mathrm{X}$ is usually a hydrophobic residue), similar to the motifs used by proline-directed kinases and phosphatases $(\mathrm{X}[\mathrm{S} / \mathrm{T}] \mathrm{PX}$ or XP[S/T]X) [106].
The proximity or competition of the $O$-GlcNAcylation sites to the phosphorylation sites in the head domain and the importance of the head domain in NF assembly [108$110]$ indicate that $O$-GlcNAcylation may also play a role in NF assembly. This regulation could be exerted by either direct or indirect (e.g. by affecting phosphorylation) influence on the structure of the head domain. It is possible that $O$-GlcNAc is added to NFPs by $O$-GlcNAc transferase $[101,102]$ right after their synthesis and prior to assembly into filaments and transport into the distal part of axons and subsequently removed by an $N$-acetyl- $\beta$-Dglucosaminidase [8].

By replacing phosphates with $O$-GlcNAc, the interaction between NFs may switch from repulsive to associative, leading to close packing of NFs, which happens in the nodes of Ranvier. Therefore, it seems likely that organization of NFs is regulated by kinase/phosphatase [111, $112]$ and $O$-GlcNAc transferase $/ N$-acetyl- $\beta$-D-glucosaminidase [101, 102, 113]. Dynamic $O$-GlcNAcylation $[105,106]$ and phosphorylation [111] could therefore regulate proper NF assembly and dynamics, and abnormalities in either of them could contribute to some of the motor neuron diseases in which NFs accumulate aberrantly $[112,114]$.

\section{Degradation}

Many neurons extend their axons over great distances, up to $1 \mathrm{~m}$ in humans, to form synapses with appropriate receptor cells. To maintain the physiological functions of the nerves, certain proteins need to have long lifetimes to span the axon. NFPs are among them. In the transport process NFP degradation is not detected. Pulse-labeling experiments indicate that the cytoskeletal proteins are metabolically stable during their passage through the axon, and essentially all of these proteins complete the trip to the axon terminus $[115,116]$. So it is believed that NFP degradation may only happen at synapses [117, 118], where dephosphorylation of NFs by the protein phosphatase 2A (PP2A) precedes NF degradation, which also indicates phosphorylation has a protective function in protecting the NFPs from degradation [119]. At the axonal terminus, the half residence time of NF is around 2 days [120]. The disintegration of NFs during pathological conditions is accounted for by the presence of calcium-activated protease (calpains) in the axoplasm [121, 122]. Calpains can degrade many different proteins, including important axonal cytoskeletal proteins such as spectrin, microtubule-associated protein-1, tau, tubulin and NFs, as well as several protein constituents of myelin (e.g. myelin basic protein, myelin-associated glycoprotein and proteolipid protein) [123]. The breakdown and turnover of NF could be accounted for by the activation of this protease in nerve terminals. It is possible that the recycling of NF degradation products represents an important feed- 
back mechanism regulating NF production. The success or failure of axonal regeneration may be determined by intrinsic neuronal factors that control the production of the axon cytoskeleton [122].

NFs synthesis was also detected in axons, but accounts for less than $1 \%$ of total $[124,125]$, and the role of this small amount of newly synthesized NFs is unknown.

\section{Functions}

\section{The basic function of NF is supporting axonal structure}

As a member of the cytoskeletal system, NFs work together with microtubules and microfilaments to enhance structural integrity, cell shape, and cell and organelle motility. The major function of NFs is to control the axonal caliber, which is related to their phosphorylation state. This is important since the speed of conductivity of an impulse down the axon is proportional to its caliber. NFs are particularly abundant in neurons with largediameter axons $(>5 \mu \mathrm{M})$ such as those of periphery motor neurons controlling skeletal muscle, where fast impulse conduction velocities are crucial for proper functioning. The first study of the role of NFs in caliber determination came from analyses of a natural mutant quail in which the NF-L gene was disrupted [126-128]. Later studies of transgenic mice lacking axonal NFs confirmed this role [129], which will be discussed more in the section on mouse models.

\section{Detrimental effects of NF accumulations}

It is well known that accumulation of NFs is a general hallmark for several neurodegenerative diseases. These include amyotrophic lateral sclerosis (ALS), Alzheimer disease (AD), Lewy bodies in Parkinson's disease (PD), progressive supranuclear palsy, Charcot-Marie-Tooth disease, diabetic neuropathy and giant axonal neuropathy [130-136].

The detrimental effect of these accumulations is seen when the protein inclusions in axons mechanically block the transportation of particles through the axon, which will eventually lead to neuronal death [46, 124, 137]. Studies showed that abnormal accumulations of NFs in the perikaryon of motor neurons can be induced by overexpressing any of the three NF subunits. Increasing the levels of NF-H or NF-M not only impairs NF transport into the axon, but also inhibits dendritic arborization [138-140]. Ma et al. [141] overexpressed human NF-L in mice and reported the severe loss of neurons in the parietal cortex and ventrobasal thalamus with age. Xu et al. [137] showed transgenic mice overexpressing $\sim 4$-fold mouse NF-L cause neuron degeneration and neuron loss, which resembles the pathology of ALS. Recently, using cells and mice overexpressing human NF-L, Sanelli et al. [142] showed that the co-localization of copper/zinc superoxide dismutase (SOD1) and neuronal nitric oxide synthase (nNOS) to NF aggregates may cause sequestration of nNOS in NF aggregates, which leads to enhanced NMDAmediated calcium influx that may cause neuron death in ALS. These results provide new insights into why NF aggregations are linked to neuronal death. All these studies emphasize the importance of subunit stoichiometry for correct NFP assembly and transport.

\section{Protective effects}

Other studies showed that NFPs have a protective effect for neuronal survival. Couillard-Després et al. [143] showed that crossing transgenic mice overexpressing human NF-H and mice expressing a mutant superoxide dismutase $\left(\mathrm{SOD} 1 \mathrm{G}^{37} \mathrm{R}\right)$ linked to human ALS increase the lifespan of the progeny by up to $65 \%$. Another example of protection by extra human NF-H came from the analysis of doubly transgenic mice that overexpress both peripherin and human NF-H transgenes [144]. The NF-H overexpression completely rescued the peripherin-mediated degeneration of motor neurons in vivo. The overexpression of human NF-H shifted the intracellular localization of peripherin from the axonal to the perikaryal compartment of spinal motor neurons, which suggests that the protective effect of extra human NF-H proteins in this situation partly come from the sequestration of peripherin into the perikaryon of motor neurons, thereby abolishing the development of axonal IF inclusions that might block transport. These findings illustrate again the importance of IF protein stoichiometry in formation, localization and potential toxicity of neuronal inclusion bodies. This is also supported by studies showing NFs were not required for pathogenesis induced by mutant SOD1, because in the absence of NF-L, with depletion of NFs in axons, life span was extended by $15 \%$ in SOD1 mutant mice [145]. All these studies support a protective effect for the depletion of axonal NFs or the accumulation of NFPs in the cell perikaryon.

Against this hypothesis, the disruption in one allele of NFL gene in mutant SOD1 mice resulting in a $40 \%$ decrease in axonal NF content and caliber of motor axons but had no effect on disease severity and life span of SOD1 mutant mice [146], which suggests that axonal depletion of NF alone was not responsible for slowing disease in mutant SOD1 mice. Their hypothesis is that perikaryal NFs can alleviate the toxicity of mutant SOD1 by sequestering $\mathrm{p} 25 / \mathrm{Cdk} 5$ complex and by acting as a phosphorylation sink for deregulated kinase activity, thereby reducing the potential toxicity of hyperphosphorylation of tau and of other Cdk substrates such as $\mathrm{Rb}[147,148]$.

Another possible explanation of NFPs, protective function may relate to the normal function of these proteins. 


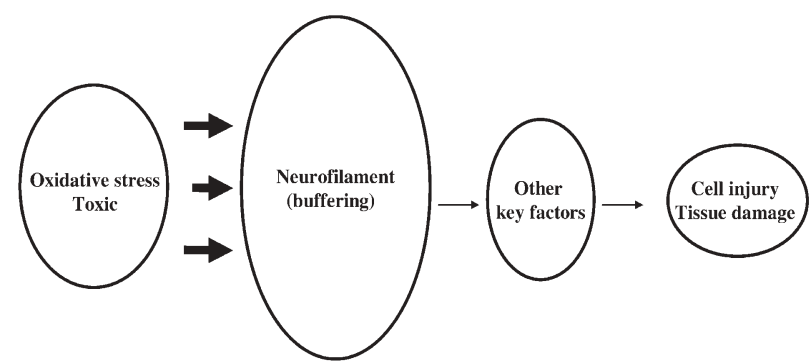

Figure 4. Hypothetical relationships among NF proteins, oxidative stress, cell injury and tissue damage. NFs, especially NF-H as the most abundant protein in neurons, may work as scavengers for oxidative stress, which protects other critical factors from oxidative attack.

In ALS, AD and control brains, axonal NF displays the most abundant carbonyl modifications in gray matter of the CNS $[149,150]$. The $205-\mathrm{kDa}$ NF-H and, to a lesser extent, the $160 \mathrm{kDa}$ NF-M, displayed the majority of the adducts of the lipid peroxidation aldehyde product hydroxynonenal (HNE) in $\mathrm{SODG}^{85} \mathrm{R}$ mutant mice and 1-33 month normal aged mice [151]. The level of HNE modification showed no difference with age in any cases. These results also support the NF sequestration hypothesis, where NFs take up toxic components, either p25/ $\mathrm{Cdk} 5$ complex or toxic products of oxidation or others, consequently leading to protection of cells and maintenance of physiological conditions [152] (fig. 4).

Many questions still remain, such as how to reconcile apparently conflicting functions of NFs. Resolution of $\mathrm{NF}$ toxicity and protection requires understanding why some NF knockout mice and NF transgenic mice are completely normal even though they have perikaryal inclusions for years, and what the initial cause(s) of the degeneration of neurons is (are). In addition to investigating the perikaryal inclusions, some effort needs to be made to determine the initial causes leading to inclusion formation.

\section{The possible function of KSP repeats}

The prominent characteristic of NF-H/M is the multiple $\mathrm{KSP}$ repeats in their C-termini, $\sim 50 \mathrm{KSP}$ repeats in NF-H $(\sim 3-13$ in NF-M) in many species. In human NF-H, there are 43-44 KSP repeats separated by 3-5 amino acids, and most of the serines in the KSP repeats are phosphorylated in axons [153]. Hyperphosphorylation of KSP repeats in the C-termini of NF-H/M may contribute to NF spacing due to charge repulsion $[59,154]$, and also prevent protease degradation during the long lifespan of these proteins [119]. Recent data from our group showed that lysine residues in KSP repeats can be adducted by carbonyls of products of oxidative stress, and the adduction is regulated by phosphorylation so that phosphorylated NF-H more readily forms HNE adducts [151 and Q. Liu and G. Perry, un- published data]. Selective absorption showed that lysine residues are the major reactive sites for HNE adduction in NFs [151]. Most of the accessible lysine sites reside in the C-termini of NF-H and NF-M in the multiple KSP repeats (human NF-H has 43-44 KSP repeats; human NF-M has 12 KSP repeats). These findings are consistent with another study that showed NFs are the major target of the elevated oxidative stress produced in spinal cord injury [155], and those showing carbonyl derivatives from glycation are also elevated in axons [104].

These data provide new insight into the function of NFs and the KSP repeats. During the lifespan of neurons, NFPs, especially NF-H, are capable of assimilating stressrelated modifications/adducts to balance cellular conditions, until they are degraded at the synapse or the modifications are reversed in the cytoplasm (fig. 5). NFPs, the major components in axons, may act as a sink for toxic carbonyls, such as HNE. The extremely low ratio of reactive species to NFPs, the reversibility of the modifications and the degradation of the modified NFs by neurons support the hypothesis that neurons can modulate the levels of oxidative modification.

Formation of NFH-HNE adducts may be a novel protective mechanism in neurons regulated by phosphorylation/ dephosphorylation that serves to buffer the axon from sudden spikes in toxic carbonyls. This mechanism may work both in physiology and pathology for the clearance of free radical products and in preventing cytoskeletal abnormalities during the neurodegenerative process. KSP repeats are likely to be one of the critical components performing this regulation.

\section{Animal models}

Many animal models have contributed to the studies for NFs in establishing NF subunit functions. The first model

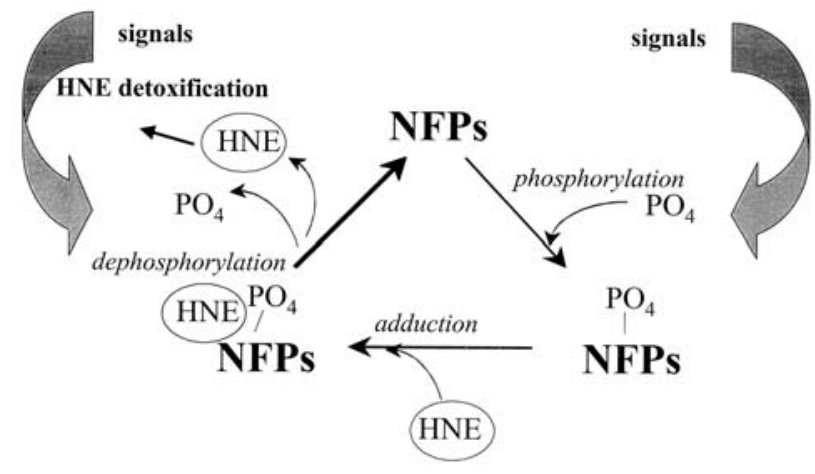

Figure 5. A hypothetical scheme for phosphorylation-dependent HNE modification of neurofilament proteins. Phosphorylation may be a regulatory factor which modulates the formation and clearance of HNE adducts. Phosphorylation on serine residues renders the lysine nearby more reactive to HNE molecules, and dephosphorylation abolishes formation of these products. 
is the Japanese quail discovered in 1991 (Quiverer) [156] with a spontaneous mutation in NF-L at amino acid 114, which is a nonsense mutant, that generates a truncated protein of only 113 amino acids of NF-L out of total 556 amino acids and is incapable of forming NFs [126]. Homozygous mutants contain no axonal NFs and exhibit mild generalized quivering. In these animals, radial growth of myelinated axons is severely attenuated [156], with consequent reduction in axonal conduction velocity [127].

The second model is the transgenic mouse reported in 1994, expressing an NF-H/ $\beta$-galactosidase fusion protein in which the C-terminus of NF-H was replaced by $\beta$-galactosidase [129]. NF inclusions in the perikarya of neurons, depletion of axonal NFs and reduced calibers were found. Later on, Zhu et al. [29] showed that mice lacking NFs due to a targeted disruption of the NF-L gene have reduced axonal calibers and delayed maturation of regenerating myelinated axons.

To demonstrate the NF subunit functions, we will only compare NF subunit knockout and overexpressing mice (table 2). To see more transgenic mice comparisons, other reviews are recommended [46, 157].

\section{NF-L knockout mice}

The targeted disruption of the NF-L gene in mice confirmed the importance of NF-L in NF assembly [29]. NF-L knockout mice had no overt phenotype. In the absence of NF-L, the levels of NF-M and NF-H subunits are dramatically decreased to $\sim 5 \%$ of normal level and unable to assemble into $10-\mathrm{nm}$ filaments. As a result, these mice have a scarcity of IF structures, severe axonal hypotrophy and no large-sized myelinated axons [29]. Levels of other cytoskeletons such as tubulin were increased, possibly as a compensating effect. While the NF-L gene knockout mice provide definite proof that NFs are a major determinant of axonal caliber, and NF-L is required for NF formation, the specific roles of NF-M and NF-H subunits remain unclear. The reduced levels of NF-H and NF-M in NF-L-/- mice are probably the result of an enhanced proteolytic turnover of unassembled or disorganized NF proteins in the absence of NF-L [29, 41, 145, 158].

\section{NF-H knockout mice}

Several laboratories have recently reported the characterization of NF-H null mice [71, 73, 90]. Surprisingly, the absence of NF-H has little effect; the mice, the NF number and the caliber of motor axons during development were all normal. With the C57B16 strain, Rao et al. [71] and Zhu et al. [90] reported only a slight reduction in the caliber of myelinated axons from the ventral roots of NF-H knockout mice; maybe the small changes are due to the increase of NF-M protein level and phosphorylation levels. MTs increased twofold with little decrease in actin level. In the mean time, the null mutant NF-H with 129J strain mice described by Elder et al. [34] exhibited a more pronounced reduction in the caliber of axons. Also, they reported little difference in NF-L and NF-M levels. These discrepancies are most likely attributable to differences in the mouse genetic backgrounds. In any case, the combined results suggest that NF-H has a minor effect on the radial growth of axons and may be a key factor interacting with $\mathrm{MT} / \mathrm{mf}$.

\section{NF-M knockout mice}

A clearer conclusion comes from the analysis of NF-M knockout mice. Two independent studies have shown that disruption of NF-M has a more severe effect than disruption of NF-H on the radial growth of large myelinated axons [31-33]. The absence of NF-M did not cause any phenotypic changes in mice but caused an increase in NF-H level and its phosphorylation. But the severe decreases in NF-L level ( $>50 \%$ ) caused axonal NF content decrease of more than $50 \%$, resulting in axonal atrophy. Compared with NF-H-/- mice, NF-M-/- mice showed that NF-M is more critical in axonal radial growth.

\section{NF-M/H double knockout mice}

Moreover, double knockout mice lacking both NF-M and NF-H subunits showed hind-limb paralysis [32, 33]. The absence of NF-M/H causes the sequestering of unassembled NF-L proteins in the neuronal perikarya, no NF formation in axons, twofold MT increase, and loss of $\sim 24 \%$ of ventral root axons $[32,33]$. The analysis of NF-M-/-, NF-H-/- double knockout mice demonstrates that the high molecular weight subunits are required for in vivo assembly of NFs and normal axonal growth.

\section{NF-L overexpressing mice}

Studies in transgenic mice have found that overexpressing mouse NF-L to 4-fold leads to a striking ALS-like pathology, in which most of the mice died before 3 weeks postnatally with only $1 / 3$ to $2 / 3$ the body weight of normal mice [137]. Also, strikingly, the only two mice surviving over 3 weeks finally recovered slowly to normality after 9 months. The transgenic mice showed intensive NF aggregation in all the compartments of neurons with depleted rough endoplasmic reticulum (RER), neuronal degeneration in both dorsal and ventral roots, phosphorylated NF-H in cell bodies and severe muscle atrophy, which resembles the human ALS pathology. This study confirmed that overexpression of NF-L and NF aggregation in mice can directly cause abnormality and degeneration of motor neurons. 
Table 2. Transgenic mouse models for NF subunit knockout or overexpression.

\begin{tabular}{|c|c|c|c|c|c|c|c|}
\hline & NF-L -/- & NF-M -/- & NF-H -l- & NF-M/H -/- & $\begin{array}{l}\text { NF-L over- } \\
\text { expression } \\
(\sim 4 \text {-fold })\end{array}$ & $\begin{array}{l}\text { NF-M over- } \\
\text { expression } \\
(\sim 2 \text {-fold })\end{array}$ & $\begin{array}{l}\text { NF-H over- } \\
\text { expression } \\
(\sim 1.2-4.5 \text {-fold })\end{array}$ \\
\hline Phenotype & no & $\begin{array}{l}\text { no (limb } \\
\text { show impaired, } \\
\text { may paralyze } \\
\text { later) }\end{array}$ & no & $\begin{array}{l}\text { paralysis in } \\
\text { hind limb }\end{array}$ & $\begin{array}{l}\text { mice died } \\
\text { before } \\
3 \text { weeks, } \\
\text { motor neuron } \\
\text { disease }\end{array}$ & no & no \\
\hline $\begin{array}{l}\text { Neuron } \\
\text { degeneration, } \\
\text { loss }\end{array}$ & no & no & no & - & yes & no & no \\
\hline NF inclusion & $\begin{array}{l}\text { yes, in } \\
\text { cell body }\end{array}$ & yes & no & no & yes, massive & $\begin{array}{l}\text { yes, both in } \\
\text { cell body } \\
\text { and axon }\end{array}$ & $\begin{array}{l}\text { yes, both } \\
\text { in cell body } \\
\text { and axon }\end{array}$ \\
\hline $\begin{array}{l}\text { Axonal } \\
\text { caliber } \\
\text { changes }\end{array}$ & $\begin{array}{l}\text { no large } \\
\text { axons }\end{array}$ & $\begin{array}{l}\text { decrease in } \\
\text { ventral roots; } \\
4 \text { month } \\
\text { decrease } 35 \% \\
\text { and } 2 \text { years } \\
\text { decrease }>70 \%\end{array}$ & $\begin{array}{l}\text { no; smaller } \\
\text { at the } \\
\text { beginning } \\
\text { but normal } \\
\text { in adult }\end{array}$ & $\begin{array}{l}\text { no large } \\
\text { axons }\end{array}$ & $\begin{array}{l}\text { increase in } \\
\text { mediate level } \\
\text { of NF-L; } \\
\text { decrease in } \\
\text { higher level }\end{array}$ & $\begin{array}{l}\text { decrease } \\
50 \%\end{array}$ & $\begin{array}{l}\text { decrease } \\
50 \%\end{array}$ \\
\hline $\begin{array}{l}\text { Axonal NF } \\
\text { change }\end{array}$ & $\begin{array}{l}\text { no NF; } \\
\sim 5 \% \text { of } \\
\text { normal } \\
\text { level of } \\
\text { NF-M/H } \\
\text { left }\end{array}$ & $\begin{array}{l}<50 \% \text { of NF \#; } \\
\text { NF-L decrease; } \\
\text { NF-H and } \\
\mathrm{PO}_{4}-\mathrm{NF}-\mathrm{H} \\
\text { increase, } \\
\alpha \text {-internexin } \\
\text { decrease }\end{array}$ & $\begin{array}{l}\mathrm{NF} \# \text { no } \\
\text { change; } \\
\mathrm{NF}-\mathrm{M} \text { and } \\
\mathrm{PO}_{4}-\mathrm{NF}-\mathrm{M} \\
\text { increase, } \\
\alpha \text {-internexin } \\
\text { decrease }\end{array}$ & $\begin{array}{l}\text { almost no } \\
\text { NF; NF-L } \\
\text { decrease } \\
\text { to } \sim 20 \% \\
\text { of normal } \\
\text { level }\end{array}$ & $\begin{array}{l}\text { NF } \\
\text { accumulation }\end{array}$ & $\begin{array}{l}\text { NF-H } \\
\text { decrease }\end{array}$ & $\begin{array}{l}\text { NF-M } \\
\text { decrease }\end{array}$ \\
\hline $\begin{array}{l}\text { Axonal IF } \\
\text { change }\end{array}$ & $\begin{array}{l}\text { MT and } \\
\text { GAP-43 } \\
\text { increase }\end{array}$ & $\begin{array}{l}\text { MT increase } \\
\text { a little } \\
(1.35 \text {-fold })\end{array}$ & $\begin{array}{l}\text { MT increase } \\
\sim 2 \text { fold; } \\
\text { Tau increase; } \\
\text { actin decrease }\end{array}$ & $\begin{array}{l}\text { MT increase } \\
\text { to } 2 \text { fold; } \\
\alpha \text {-internexin } \\
\text { decrease }\end{array}$ & - & - & no \\
\hline $\begin{array}{l}\text { Axonal } \\
\text { transport } \\
\text { velocity } \\
\text { of NF }\end{array}$ & - & $\begin{array}{l}\text { increase to } \\
2 \text {-fold }\end{array}$ & increase & $\begin{array}{l}\text { increase to } \\
2 \text {-fold }\end{array}$ & - & - & $\begin{array}{l}\text { decrease } \\
>2-3 \text {-fold }\end{array}$ \\
\hline $\begin{array}{l}\text { Conduction } \\
\text { velocity }\end{array}$ & $\begin{array}{l}\text { decrease } \\
70 \%\end{array}$ & $\begin{array}{l}\text { decrease } \\
40 \%\end{array}$ & $\begin{array}{l}\text { decrease } \\
40 \%\end{array}$ & - & - & - & - \\
\hline Indication & $\begin{array}{l}\mathrm{NF}-\mathrm{L} \text { is } \\
\text { responsible } \\
\text { for NF } \\
\text { formation }\end{array}$ & $\begin{array}{l}\text { NF-M is } \\
\text { more critical } \\
\text { in axonal } \\
\text { caliber } \\
\text { than NF-H }\end{array}$ & $\begin{array}{l}\mathrm{NF}-\mathrm{H} \text { is the } \\
\text { key factor } \\
\text { to interact } \\
\text { with MT } \\
\text { and actin }\end{array}$ & $\begin{array}{l}\mathrm{NF}-\mathrm{M} / \mathrm{H} \text { are } \\
\text { needed for } \\
\mathrm{NF} \text { assembly } \\
\text { in vivo } \\
\text { and other } \\
\text { key factors } \\
\text { needed to form } \\
\text { long-range } \\
\text { interaction }\end{array}$ & $\begin{array}{l}\text { NF-L 4-fold } \\
\text { overexpression } \\
\text { caused } \\
\text { ALS-like } \\
\text { disease; NF } \\
\text { accumulation } \\
\text { can cause ND } \\
\text { directly }\end{array}$ & $\begin{array}{l}\text { NF-M } \\
\text { overexpres- } \\
\text { sion did } \\
\text { not cause } \\
\text { neuron } \\
\text { degenera- } \\
\text { tion }\end{array}$ & $\begin{array}{l}\text { NF-H } 4.5 \text {-fold } \\
\text { overexpression } \\
\text { did not cause } \\
\text { ND, so the } \\
\text { slowing of } \\
\text { transport only } \\
\text { is not the } \\
\text { reason for ND }\end{array}$ \\
\hline Reference & {$[28,72]$} & {$[30-32,72]$} & {$[32,72,89]$} & [30-32] & [135] & {$[136]$} & [137] \\
\hline
\end{tabular}

The summary and comparison of NF subunit knockout and overexpression mouse models.

'-' means not found in the original papers. 


\section{NF-M overexpressing mice}

The NF-M overexpressing transgenic mice appeared normal [138]. With 2-fold increase in the total (WT plus mutant) NF-M level in the mice, accumulation of NFs was detected in cell bodies and axons. The axonal caliber of neurons decreased $\sim 50 \%$ with unchanged NF-L level and $50 \%$ decrease of WT NF-H and WT NF-M levels. This caliber reduction is a result of growth retardation rather than total growth inhibition, which was restored to the normal level with time, and it is correlated with reduction of WT NF-H and WT NF-M. No neuronal degeneration was detected. Because the nearest interneurofilament spacing did not change, this reduction may be strictly correlated with NF numbers.

\section{NF-H overexpressing mice}

Overexpressing 1.2- to 4.5-fold of WT NF-H in transgenic mice showed no overt phenotypes or neuron loss [139, 175]. The level of NF-M in axons was correlatively reduced with the increased NF-H level, and the NF-L level decreased $20 \%-40 \%$ in axons. Axonal caliber reduction was correlated with the level of NF-H overexpression, and $>3$-fold NF-H overexpression totally inhibited large axon growth. This caliber reduction can also be considered as strictly correlated with NF-M level or NF numbers.

In all these studies, only mice overexpressing $>3$-fold NF-L and NF-M/H double knockout mice showed severe phenotypes. Taken together, these data clearly demonstrate all the NF subunit functions: expression of NF-L is responsible for NF assembly, and NF-M/H subunits are required for NF assembly in vivo; NF-M is more critical for axonal growth than NF-H, and the latter may be working as a key factor for NF interaction with other cytoskeletal polymers. The nearest interneurofilament spacing does not change when NFs are presented in the axons, but to achieve the long-range 'cross-bridges', the side chains of NF-H and other key factors are definitely required. Expression of NF-M and NF-H are coregulated in an inverse manner in motor axons, and they are competing for transport and assembly with NF-L. In largecaliber axons, microtubule content does not correlate with axonal diameter as closely as does NF content $[159,160]$, but microtubule or other IFs are more significant in maintaining the diameter of medium- and smallsized axons, where they are the major cytoskeletal components.

Notably, studies other than those above also provide solid evidence for NF function. Recently, research on NF-H truncated mutant mice [35] suggests that neither the C-terminal tail of NF-H nor its phosphorylation is important for axonal caliber. Transgenic mice with human NF subunits $[161,162]$ or mutations in mouse NFs $[35,163]$ all showed severe motor neuron degeneration, which indicates that non-WT NF forms may be the major factors for neuronal degeneration. Also, studies with SOD mutant mice which utilized human NF subunits provide additional important information [164-167].

\section{NFs and neurodegenerative diseases}

Abnormal accumulation of NFs is detected in many human neurodegenerative disorders, including ALS, AD, dementia with Lewy bodies, Parkinson disease and diabetes, among others. Many alterations can potentially lead to accumulation of NFPs, including dysregulation of NFP synthesis, defective axonal transport, abnormal phosphorylation and proteolysis. Studies in transgenic mice also showed that NFs affect the dynamics and function of other cytoskeletal elements, such as microtubules and actin filaments $[90,168]$. It is widely believed that $\mathrm{NF}$ abnormalities in neurodegenerative disorders are the hallmark of neuronal dysfunction.

\section{ALS}

ALS is a motor neuron disease, also called Lou Gehrig's disease, first identified in 1869 by the noted French neurologist Jean-Martin Charcot. ALS affects as many as 20,000 Americans, with 5000 new cases occurring in the United States each year, typically with an onset between 40 and 60 years of age. Men's risk is about 1.5 times that of women. ALS is usually fatal within 5 years after diagnosis. It is a progressive neurodegenerative disease that attacks motor neurons in the brain and spinal cord. The progressive degeneration of the motor neurons in ALS eventually leads to neuron death and loss of related muscle movements. Patients of ALS become partially or totally paralyzed, but most of the patients' cognitive functions remain unaffected. There is no cure, but the Food and Drug Administration (FDA) recently approved riluzole, a drug that has been shown to prolong the survival of ALS patients.

A key neuropathological hallmark of ALS is intraneuronal aggregates of NFs in degenerating motor neurons $[75,169-174]$. Although the reason for the NF aggregates is unclear, transgenic mouse models which overexpress any of the NF subunits (NFL, NFM and NFH) will provoke motor neuropathy characterized by the presence of abnormal NF accumulations resembling those found in ALS [137, 138, 165, 176]. Remarkably, motor neuropathy in transgenic mice overexpressing human NF-H was rescued by restoring a correct stoichiometry of NF-L to NF-H subunits with the co-expression of human NF-L transgene [167]. It has been proposed that such alterations in NF homeostasis are directly relevant to the pathogenesis of ALS [145].

Interestingly, abnormal NF inclusions are often associated with decreases in levels of NF-L mRNA. NF-L 
mRNA is selectively reduced by up to $70 \%$ in degenerating neurons of ALS and AD [176-179]. A decrease in the NF-L mRNA level occurs with a decrease of $\alpha$-internexin or peripherin mRNA levels, suggesting an absolute alteration of the stoichiometry of NF expression in ALS $[177,178]$.

Also, codon deletions or insertions in the KSP regions of NF-H have been detected in a small number of sporadic cases of ALS, including a large deletion of five KSP repeats [180-182]. Taken together, these observations suggest a significant alternation in NF expression in ALS.

\section{AD}

$\mathrm{AD}$ is a CNS neurodegenerative disease. It was first described in 1906 by German physician Dr Alois Alzheimer [6]. Although the disease was once considered rare, it is now established as the leading cause of dementia. An estimated 4 million individuals in the United States have Alzheimer's disease, with an annual expense of about $\$ 70-\$ 100$ billion, and as many as 350,000 individuals develop the disease each year [183]. The risk of $\mathrm{AD}$ varies from 12 to $19 \%$ for women over the age of 65 years and 6 to $10 \%$ for men [184]. On average, AD patients live about 8 years after they are diagnosed, although the disease can last for as many as 20 years. The areas of the brain that control memory and thinking skills are affected first, but as the disease progresses, cells die in other regions of the brain. Eventually, the person with $\mathrm{AD}$ will need complete care. If the individual has no other serious illness, the loss of brain function itself will cause death. There is no cure, and the only therapy known are cholinesterase inhibitors or anti-cholinesterase drugs, including Reminyl (galantamine), Aricept (donepezil hydrochloride) and Exelon (rivastigmine), which provide symptomatic relief but do little to slow disease progression.

After the last 2 decades of intensive studies, more information is available, but the cause of AD is still unknown. Many hypotheses have been proposed, such as amyloid- $\beta$ cascade [185], tauopathy [186], inflammation [187, 188] and oxidative stress [189-193].

Cytoskeleton disruption is a prominent feature and secondary event followed by oxidative damage in Alzheimer disease $[149,168,194]$. NFT as the hallmark of AD is composed of abnormally modified $\tau$, NFs and other cytoskeleton proteins. The cause for the aberrant biochemical processes that transform normal $\tau$ and NF into abnormal filaments is not understood.

In $\mathrm{AD}$, inappropriate hyperphosphorylation of proteins such as $\tau$ and NF is prominent, which is likely due to perturbation in the balance between kinases and phosphatase activities [195]. MAP kinase [196], GSK-3 [197] and CDK $5[198,199]$ pathways are known to be involved in $\tau$ and NF phosphorylation in neurons. One of the earliest changes noted in $\mathrm{AD}$ is accumulation of hyperphosphorylated $\tau$ and NF in normal perikarya [74-77]. This abnormal hyperphosphorylation may cause protein aggregation in NFT in AD neurons. The role of NFT and senile plaques in $\mathrm{AD}$ are still actively disputed.

\section{PD}

PD is a progressive disorder of the CNS. The disease was originally described in 1817 by an English physician, James Parkinson, who called it shaking palsy. It affects more than 1.5 million people in the United States. Men and women are similarly affected. The frequency of the disease is considerably higher in the over-60 age group, and the average duration of illness is about 9 years [200].

PD is caused by degeneration of the pigmented neurons in the substantia nigra of the brain, resulting in decreased dopamine availability. Clinically, the disease is characterized by a decrease in spontaneous movements, gait difficulty, postural instability, rigidity and tremor. Only in the 1960s, however, were pathological and biochemical changes in the brain of patients identified, opening the way to the first effective medication for the disease. Administration of the drug levodopa, a dopamine precursor, has been the standard treatment for PD.

The major pathological change of PD is an accumulated protein inclusion called the Lewy body, composed of numerous proteins, including the essential constituent of $\alpha$-synuclein protein, the three NF subunits [201], ubiquitin and proteasome subunits [202]. Electron microscopy and biochemical evidence indicate that the abnormally phosphorylated NFs form a non-membrane-bounded compacted skein in the neuronal soma in the affected neurons.

In familial PD, mutations in the Parkin gene is the major cause, in which over 20 different mutations have been identified [203-206].

More recently, a point mutation has been reported in the region of the NEFM gene coding for the rod domain 2B of NF-M in an individual with PD [207]. The base pair change results in substitution of serine for glycine at residue 336, and probably disrupts assembly. The patient developed PD at the very young age of 16 . Although this is an isolated report, and three other unaffected family members also carried the mutation, it is possible that this mutation is responsible for the young onset of an aggressive form of PD. It is already known that mutations in the same region of neurofilament proteins might cause a peripheral motor nerve axonal loss in NEFL and central dopaminergic loss in NEFM. It has also been found that NF-L mRNA decreased in PD, correlating with the severity of the disease [208]. 


\section{Charcot-Marie-Tooth disease (CMT)}

CMT is the most common inherited neurological disorder. It was discovered in 1886 by three physicians, JeanMarie-Charcot, Pierre Marie and Howard Henry Tooth. Approximately 150,000 Americans are affected by the condition. CMT affects both motor neurons and sensory neurons to the muscles, and patients slowly lose normal use of their feet/legs and hands/arms as nerves to the extremities degenerate. The loss of nerve function in the extremities also leads to sensory loss. The ability to distinguish hot and cold is diminished as well as the sense of touch. There are several types of CMT, but the simplest classification is into types 1,2 and 3. Types 1 and 3 are due to demyelinization, and type 2 is an axonal disease. CMT is generally inherited in an autosomal dominant pattern. At present there is no cure for CMT, although physical therapy and moderate activity are often recommended to maintain muscle strength and endurance.

Several families have now been identified in which heterozygosity for mutations of the NEFL gene on chromosome 8 are associated with CMT2 [209-212].

The first of these changes is a proline at residue 8 to glutamine. The second change is a leucine to a proline residue at position 333 in the highly conserved rod domain 2B.

These NEFL CMT2 mutations disrupt NF assembly and axonal transport, and this probably underlies the disease mechanism. A mouse model with a mutation in the same coil, leucine to proline at residue 394, develops severe selective motor neuron death because of disruption of neurofilament assembly [163]. Georgiou et al. [211] identified a novel NF-L missense mutation $\left(\mathrm{Cys}^{64} \mathrm{Thr}\right)$ that caused the disease in a large Slovenian CMT2 family. This mutation results in a proline-to-serine substitution at codon $22\left(\mathrm{Pro}^{22} \mathrm{Ser}\right)$, and the mutation showed complete co-segregation with the dominantly inherited CMT2 phenotype in this family. A similar Pro ${ }^{22} \mathrm{Thr}$ was also detected in unrelated Japanese patients with CMT disease [212, 213]. Jordanova et al. [212] found six pathogenic missense mutations and one 3-bp inframe deletion in the NF-L gene in 323 patients with different CMT phenotypes.

Some types of CMT are caused by defects in proteins expressed in the Schwann cell, including the connexin 32 (CX32/GJB1) genes. Such mutations result in aberrant myelination and altered NF phosphorylation. In such cases, therefore, abnormalities of neurofilament phosphorylation occur downstream of the primary pathological process but are still upstream of the end point.

\section{Diabetes}

Diabetes is a disease in which the body does not produce or properly use insulin. The cause of diabetes continues to be a mystery, although both genetics and environmental factors such as obesity and lack of exercise appear to play roles. There are 18.2 million people in the United States, or $6.3 \%$ of the population, who have diabetes. It is estimated that at least 20.1 million Americans have pre-diabetes, in addition to the 18.2 million with diabetes. About $65 \%$ of deaths among people with diabetes are due to heart disease and stroke.

Diabetes is associated with a symmetrical distal axonal neuropathy. The neuropathy is predominantly in sensory neurons or dorsal root ganglia. The dorsal root ganglia of rats with streptozocin-induced diabetes have an increase in phosphorylation of NFs in lumbar dorsal root ganglia, but not in other neural cell types [214]. This is probably the result of activation of c-Jun N-terminal kinase (JNK), which is a NF kinase. Pathologically, neurites from sympathetic ganglia are swollen with disorganized aggregates of NFs and other proteins, including peripherin [134]. Many of these studies show that NF abnormalities can be primary causes of disease and that NF changes may not simply be a passive marker of pathological processes.

The neuropathy associated with diabetes includes welldocumented impairment of axonal transport, a reduction in axon caliber and a reduced capacity for nerve regeneration. All of those aspects of nerve function rely on the integrity of the axonal cytoskeleton. mRNAs for NFPs are selectively reduced in the diabetic rat, and posttranslational modification of at least one of the NFPs is altered. There is some evidence that altered expression of isoforms of protein kinases may contribute to these changes. Tubulin and actin aberrant modifications are also found [215].

The list of diseases involved with NF abnormalities will likely increase, and the common mechanism for all the protein aggregation diseases may soon be recognized [216].

\section{Summary}

In this review, we summarized as many as 11 aspects of NF, which may provide some help for the overall knowledge of the readers. Future studies will focus on functions, interactions and pathology of NFs in normal axon development and neurodegenerative diseases, which will provide more knowledge and value for NFs. Hopefully, in the near future, effective therapeutic methods for these neurodegenerative diseases will be available for the public.

1 National Library of Medicine's Unified Medical Language System (UMLS), http://ghr.nlm.nih.gov/ghr/glossary/neurofilament, accessed 21 June 2004

2 Valentin G. (1836) Über den Verlauf und die letzten Enden der Nerven. Nova Acta Physico-Medica Academiae Caesareae Leopoldino-Carolinae 18: 51-71

3 Purkinje J. E. (1838) Untersuchungen aus der nerven und himanatomie. Ber. Versamml. deut. Naturforsch. u. Arzte (Prague), p. 177 
4 Apathy S. (1897) Nach welcher Richtung hin soll die Nervenlehre reformiert werden. Biol. Zentralal. 9: 527-648

5 Cajal S. R. (1903) Embryogenesis of neurofibrils. Trab. Lab Investigaciones Biol. Univ. Madrid 2: 219-225

6 Alzheimer A. (1906) Neurolisches Zentralblatt 25: 1134

7 Shaw G. (1991) Neurofilament proteins. In: The Neuronal Cytoskeleton, pp. 5-74, Burgoyne R. D. (ed.), Wiley, New York

8 Dong D. L., Xu Z. S., Chevrier M. R., Cotter R. J., Cleveland D. W. and Hart G. W. (1993) Glycosylation of mammalian neurofilaments. Localization of multiple O-linked N-acetylglucosamine moieties on neurofilament polypeptides $\mathrm{L}$ and M. J. Biol. Chem. 268: 16679-16687

9 Morris J. R. and Lasek R. J. (1982) Stable polymers of the axonal cytoskeleton: the axoplasmic ghost. J. Cell Biol. 92: 192-198

10 Morris J. R. and Lasek R. J. (1984) Monomer-polymer equilibria in the axon: direct measurement of tubulin and actin as polymer and monomer in axoplasm. J. Cell Biol. 98: 20642076

11 Fuchs E. and Weber K. (1994) Intermediate filaments: structure, dynamics, function and disease. Annu. Rev. Biochem. 63: $345-382$

12 Al-Chalabi A. and Miller C. C. (2003) Neurofilaments and neurological disease. Bioessays 25: 346-355

13 Shaw G. and Weber K. (1982) Differential expression of neurofilament triplet proteins in brain development. Nature 298: $277-279$

14 Carden M. J., Trojanowski J. Q., Schlaepfer W. W. and Lee V. M. (1987) Two-stage expression of neurofilament polypeptides during rat neurogenesis with early establishment of adult phosphorylation patterns. J. Neurosci. 7: 3489-3504

15 Nixon R. A. and Shea T. B. (1992) Dynamics of neuronal intermediate filaments: a developmental perspective. Cell Motil. Cytoskeleton 22: 81-91

16 Willard M. and Simon C. (1983) Modulations of neurofilament axonal transport during the development of rabbit retinal ganglion cells. Cell 35: 551-559

17 Strausberg R. L., Feingold E. A., Grouse L. H., Derge J. G., Klausner R. D., Collins F. S. et al. (2002) Generation and initial analysis of more than 15,000 full-length human and mouse cDNA sequences. Proc. Natl. Acad. Sci. USA 99: 16899-16903

18 Myers M. W., Lazzarini R. A., Lee V. M., Schlaepfer W. W. and Nelson D. L.(1987) The human mid-size neurofilament subunit: a repeated protein sequence and the relationship of its gene to the intermediate filament gene family. EMBO J. 6: $1617-1626$

19 Lees J. F., Shneidman P. S., Skuntz S. F., Carden M. J. and Lazzarini R. A. (1988) The structure and organization of the human heavy neurofilament subunit $(\mathrm{NF}-\mathrm{H})$ and the gene encoding it. EMBO J. 7: 1947-1955

20 Breen K. C. and Anderton B. H. (1991) Temporal expression of neurofilament polypeptides in differentiating neuroblastoma cells. Neuroreport 2: 21-24

21 Ching G. Y. and Liem R. K. (1993) Assembly of type IV neuronal intermediate filaments in nonneuronal cells in the absence of preexisting cytoplasmic intermediate filaments. J. Cell Biol. 122: 1323-1335

22 Lee M. K., Xu Z., Wong P. C. and Cleveland D. W. (1993) Neurofilaments are obligate heteropolymers in vivo. J. Cell Biol. 122: 1337-1350

23 Heins S. and Aebi U. (1994) Making heads and tails of intermediate filament assembly, dynamics and networks. Curr. Opin. Cell Biol. 6: 25-33

24 Fuchs E. and Cleveland D. W. (1998) A structural scaffolding of intermediate filaments in health and disease. Science 279: 514-519

25 Herrmann H. and Aebi U. (2000) Intermediate filaments and their associates: multi-talented structural elements specifying cytoarchitecture and cytodynamics. Curr. Opin. Cell Biol. 12: 79-90

26 Herrmann H., Haner M., Brettel M., Ku N. O. and Aebi U. (1999) Characterization of distinct early assembly units of different intermediate filament proteins. J. Mol. Biol. 286: 14031420

27 Carden M. J., Trojanowski J. Q., Schlaepfer W. W. and Lee V. M. (1987) Two-stage expression of neurofilament polypeptides during rat neurogenesis with early establishment of adult phosphorylation patterns. J. Neurosci. 7: 34893504

28 Perrone Capano C., Pernas-Alonso R. and di Porzio U. (2001) Neurofilament homeostasis and motoneurone degeneration. Bioessays 23: 24-33

29 Zhu Q., Couillard-Despres S. and Julien J.P. (1997) Delayed maturation of regenerating myelinated axons in mice lacking neurofilaments. Exp. Neurol. 148: 299-316

30 Elder G. A., Friedrich V. L. Jr., Bosco P., Kang C., Gourov A., Tu P. H., et al. (1998) Absence of the mid-sized neurofilament subunit decreases axonal calibers, levels of light neurofilament (NF-L), and neurofilament content. J. Cell Biol. 141: 727-739

31 Elder G. A., Friedrich V. L. Jr, Margita A. and Lazzarini R. A. (1999) Age-related atrophy of motor axons in mice deficient in the mid-sized neurofilament subunit. J. Cell Biol. 146: 181-192

32 Elder G. A., Friedrich V. L. Jr, Pereira D., Tu P. H., Zhang B., Lee V. M., et al. (1999) Mice with disrupted midsized and heavy neurofilament genes lack axonal neurofilaments but have unaltered numbers of axonal microtubules. J. Neurosci. Res. 57: 23-32

33 Jacomy H., Zhu Q., Couillard-Despres S., Beaulieu J. M. and Julien J. P. (1999) Disruption of type IV intermediate filament network in mice lacking the neurofilament medium and heavy subunits. J. Neurochem. 73: 972-984

34 Elder G. A., Friedrich V. L. Jr, Kang C., Bosco P., Gourov A., Tu P. H. et al. (1998) Requirement of heavy neurofilament subunit in the development of axons with large calibers. J. Cell Biol. 143: 195-205

35 Rao M. V., Garcia M. L., Miyazaki Y., Gotow T., Yuan A., Mattina S. et al. (2002) Gene replacement in mice reveals that the heavily phosphorylated tail of neurofilament heavy subunit does not affect axonal caliber or the transit of cargoes in slow axonal transport. J. Cell Biol. 158: 681-693

36 Nakagawa T., Chen J., Zhang Z., Kanai Y. and Hirokawa N. (1995) Two distinct functions of the carboxyl-terminal tail domain of NF-M upon neurofilament assembly: cross-bridge formation and longitudinal elongation of filaments. J. Cell Biol. 129: 411-429

37 Geisler N. and Weber K. (1981) Self-assembly in vitro of the 68,000 molecular weight component of the mammalian neurofilament triplet proteins into intermediate-sized filaments. J. Mol. Biol. 151: 565-571

38 Liem R. K. and Hutchison S. B. (1982) Purification of individual components of the neurofilament triplet: filament assembly from the 70 000-dalton subunit. Biochemistry 21: 3221-3226

39 Carter J., Gragerov A., Konvicka K., Elder G., Weinstein H. and Lazzarini R. A. (1998) Neurofilament (NF) assembly; divergent characteristics of human and rodent NF-L subunits. J. Biol. Chem. 273: 5101-5108

40 Cui C., Stambrook P. J. and Parysek L. M. (1995) Peripherin assembles into homopolymers in SW13 cells. J. Cell Sci. 108: 3279-3284

41 Beaulieu J. M., Nguyen M. D. and Julien J. P. (1999) Late onset death of motor neurons in mice overexpressing wildtype peripherin. J. Cell Biol. 147: 531-544

42 Beaulieu J. M., Robertson J. and Julien J. P. (1999) Interactions between peripherin and neurofilaments in cultured 
cells: disruption of peripherin assembly by the NF-M and NF-H subunits. Biochem. Cell. Biol. 77: 41-45

43 Fliegner K. H. and Liem R. K. (1991) Cellular and molecular biology of neuronal intermediate filaments. Int. Rev. Cytol. 131: 109-167

44 Kaplan M. P., Chin S. S., Fliegner K. H. and Liem R. K. (1990) Alpha-internexin, a novel neuronal intermediate filament protein, precedes the low molecular weight neurofilament protein (NF-L) in the developing rat brain. J. Neurosci. 10: $2735-2748$

45 Fliegner K. H., Kaplan M. P., Wood T. L., Pintar J. E. and Liem R. K. (1994) Expression of the gene for the neuronal intermediate filament protein alpha-internexin coincides with the onset of neuronal differentiation in the developing rat nervous system. J. Comp. Neurol. 342: 161-173

46 Lariviere R. C. and Julien J. P. (2004) Functions of intermediate filaments in neuronal development and disease. J. Neurobiol. 58(1): 131-148

47 Baas P. and Brown A. (1997) Slow axonal transport: the polymer transport model. Trends Cell Biol. 7: 380-384

48 Baas P. W. (1997) Microtubules and axonal growth. Curr. Opin. Cell Biol. 9: 29-36

49 Hirokawa N. (1997) The mechanisms of fast and slow transport in neurons: identification and characterization of the new kinesin superfamily motors. Curr. Opin. Neurobiol. 7: 605-614

50 Nixon R. A. (1998) Dynamic behavior and organization of cytoskeletal proteins in neurons: reconciling old and new findings. Bioessays 20: 798-807

51 Nixon R. A. (1998) The slow axonal transport debate. Trends Cell Biol. 8: 100

52 Nixon R. A. (1998) The slow axonal transport of cytoskeletal proteins. Curr. Opin. Cell Biol. 10: 87-92

53 Okabe S. and Hirokawa N. (1990) Turnover of fluorescently labelled tubulin and actin in the axon. Nature 343: 479-482

54 Roy S., Coffee P., Smith G., Liem R. K., Brady S. T. and Black M. M. (2000) Neurofilaments are transported rapidly but intermittently in axons: implications for slow axonal transport. J. Neurosci. 20: 6849-6861

55 Wang L., Ho C. L., Sun D., Liem R. K. and Brown A. (2000) Rapid movement of axonal neurofilaments interrupted by prolonged pauses. Nat. Cell Biol. 2: 137-141

56 Prahlad V., Helfand B. T., Langford G. M., Vale R. D. and Goldman R. D. (2000) Fast transport of neurofilament protein along microtubules in squid axoplasm. J. Cell Sci. 113: 39393946

57 Yabe J. T., Pimenta A. and Shea T. B. (1999) Kinesin-mediated transport of neurofilament protein oligomers in growing axons. J. Cell Sci. 112: 3799-3814

58 Hsieh S. T., Kidd G. J., Crawford T. O., Xu Z., Lin W. M., Trapp B. D. et al. (1994) Regional modulation of neurofilament organization by myelination in normal axons. J. Neurosci. 14: 6392-6401

59 de Waegh S. M., Lee V. M. and Brady S. T. (1992) Local modulation of neurofilament phosphorylation, axonal caliber and slow axonal transport by myelinating Schwann cells. Cell 68: $451-463$

60 Cole J. S., Messing A., Trojanowski J. Q. and Lee. V. M. (1994) Modulation of axon diameter and neurofilaments by hypomyelinating Schwann cells in transgenic mice. J. Neurosci. 14: 6956-6966

61 Jaffe H., Veeranna, Shetty K. T. and Pant H. C. (1998) Characterization of the phosphorylation sites of human high molecular weight neurofilament protein by electrospray ionization tandem mass spectrometry and database searching. Biochemistry 37: 3931-3940

62 Sternberger L. A. and Sternberger N. H. (1983) Monoclonal antibodies distinguish phosphorylated and nonphosphorylated forms of neurofilaments in situ. Proc. Natl. Acad. Sci. USA 80: $6126-6130$
63 Oblinger M. M., Brady S. T., McQuarrie I. G. and Lasek R. J. (1987) Cytotypic differences in the protein composition of the axonally transported cytoskeleton in mammalian neurons. J. Neurosci. 7: 453-462

64 Nixon R. A., Paskevich P. A., Sihag R. K. and Thayer C. Y. (1994) Phosphorylation on carboxyl terminus domains of neurofilament proteins in retinal ganglion cell neurons in vivo: influences on regional neurofilament accumulation, interneurofilament spacing and axon caliber. J. Cell Biol. 126: 1031-1046

65 Pant H. C., Veeranna (1995) Neurofilament phosphorylation. Biochem. Cell Biol. 73: 575-592

66 Komiya Y., Cooper N. A. and Kidman A. D. (1986) The longterm effects of a single injection of beta,beta'-iminodipropionitrile on slow axonal transport in the rat. J. Biochem. 100: 1241-1246

67 Lee V. M., Otvos L. Jr, Schmidt M. L. and Trojanowski J. Q. (1988) Alzheimer disease tangles share immunological similarities with multiphosphorylation repeats in the two large neurofilament proteins. Proc. Natl. Acad. Sci. USA 85: 7384-7388

68 Yin X., Crawford T. O., Griffin J. W., Tu P., Lee V. M., Li C. et al. (1998) Myelin-associated glycoprotein is a myelin signal that modulates the caliber of myelinated axons. J. Neurosci. 18: $1953-1962$

69 Sanchez I., Hassinger L., Paskevich P. A., Shine H.D. and Nixon R. A. (1996) Oligodendroglia regulate the regional expansion of axon caliber and local accumulation of neurofilaments during development independently of myelin formation. J. Neurosci. 16: 5095-5105

70 Sanchez I., Hassinger L., Sihag R. K., Cleveland D. W., Mohan P. and Nixon R. A. (2000) Local control of neurofilament accumulation during radial growth of myelinating axons in vivo. Selective role of site-specific phosphorylation. J. Cell Biol. 151: 1013-1024

71 Rao M. V., Houseweart M. K., Williamson T. L., Crawford T. O., Folmer J. and Cleveland D. W. (1998) Neurofilamentdependent radial growth of motor axons and axonal organization of neurofilaments does not require the neurofilament heavy subunit (NF-H) or its phosphorylation. J. Cell Biol. 143: $171-181$

72 Rao M. V., Campbell J., Yuan A., Kumar A., Gotow T., Uchiyama Y. et al. (2003) The neurofilament middle molecular mass subunit carboxyl-terminal tail domains is essential for the radial growth and cytoskeletal architecture of axons but not for regulating neurofilament transport rate. J. Cell Biol. 163: $1021-1031$

73 Kriz J., Zhu Q., Julien J.P. and Padjen A. L. (2000) Electrophysiological properties of axons in mice lacking neurofilament subunit genes: disparity between conduction velocity and axon diameter in absence of NF-H. Brain Res. 885: 32-44

74 Sternberger N. H., Sternberger L. A. and Ulrich J. (1985) Aberrant neurofilament phosphorylation in Alzheimer disease. Proc. Natl. Acad. Sci. USA 82: 4274-4276

75 Manetto V., Sternberger N. H., Perry G., Sternberger L. A. and Gambetti P. (1988) Phosphorylation of neurofilaments is altered in amyotrophic lateral sclerosis. J. Neuropathol. Exp. Neurol. 47: 642-653

76 Sobue G., Hashizume Y., Yasuda T., Mukai E., Kumagai T., Mitsuma T. et al. (1990) Phosphorylated high molecular weight neurofilament protein in lower motor neurons in amyotrophic lateral sclerosis and other neurodegenerative diseases involving ventral horn cells. Acta Neuropathol. 79: 402-408

77 Cleveland D. W. and Rothstein J. D. (2001) From Charcot to Lou Gehrig: deciphering selective motor neuron death in ALS. Nat. Rev. Neurosci. 2: 806-819

78 Sihag R. K. and Nixon R. A. (1989) in vivo phosphorylation of distinct domains of the 70-kilodalton neurofilament subunit involves different protein kinases. J. Biol. Chem. 264: $457-464$ 
79 Sihag R. K. and Nixon R. A. (1991) Identification of Ser-55 as a major protein kinase A phosphorylation site on the 70$\mathrm{kDa}$ subunit of neurofilaments. Early turnover during axonal transport. J. Biol. Chem. 266: 18861-18867

80 Hisanaga S. and Hirokawa N. (1990) Molecular architecture of the neurofilament. II. Reassembly process of neurofilament L protein in vitro. J. Mol. Biol. 211: 871-882

81 Hisanaga S., Matsuoka Y., Nishizawa K., Saito T., Inagaki M. and Hirokawa N. (1994) Phosphorylation of native and reassembled neurofilaments composed of NF-L, NF-M, and $\mathrm{NF}-\mathrm{H}$ by the catalytic subunit of cAMP-dependent protein kinase. Mol. Biol. Cell 5: 161-172

82 Nakamura Y., Hashimoto R., Kashiwagi Y., Aimoto S., Fukusho E., Matsumoto N. et al. (2000) Major phosphorylation site (Ser55) of neurofilament L by cyclic AMP-dependent protein kinase in rat primary neuronal culture. J. Neurochem. 74: 949-959

83 Gibb B. J., Robertson J. and Miller C. C. (1996) Assembly properties of neurofilament light chain Ser55 mutants in transfected mammalian cells. J. Neurochem. 66: 1306-1311

84 Gibb B. J., Brion J. P., Brownlees J., Anderton B. H. and Miller C. C. (1998) Neuropathological abnormalities in transgenic mice harbouring a phosphorylation mutant neurofilament transgene. J. Neurochem. 70: 492-500

85 Ching G. Y. and Liem R. K. (1999) Analysis of the roles of the head domains of type IV rat neuronal intermediate filament proteins in filament assembly using domain-swapped chimeric proteins. J. Cell Sci. 112: 2233-2240

86 Zheng Y. L., Li B. S., Veeranna and Pant H. C. (2003) Phosphorylation of the head domain of neurofilament protein (NF-M): a factor regulating topographic phosphorylation of NF-M tail domain KSP sites in neurons. J. Biol. Chem. 278: 24026-24032

87 Shea T. B. (2000) Microtubule motors, phosphorylation and axonal transport of neurofilaments. J. Neurocytol. 29: 873-887

88 Lewis S. E. and Nixon R. A. (1988) Multiple phosphorylated variants of high molecular weight subunit of neurofilaments of retinal cell neurons: characterization and evidence for their differential association with stationary and moving neurofilaments. J. Cell Biol. 107: 2689-2701

89 Nixon R. A. and Sihag R. K. (1991) Neurofilament phosphorylation: a new look at regulation and function. Trends Neurosci. 14: 501-506

90 Zhu Q., Lindenbaum M., Levavasseur F., Jacomy H. and Julien J. P. (1998) Disruption of the NF-H gene increases axonal microtubule content and velocity of neurofilament transport: relief of axonopathy resulting from the toxin beta, beta'-iminodipropionitrile. J. Cell Biol. 143: 183-193

91 Jung C., Yabe J. T., Lee S. and Shea T. B. (2000) Hypophosphorylated neurofilament subunits undergo axonal transport more rapidly than more extensively phosphorylated subunits in situ. Cell Motil. Cytoskeleton 47: 120-129

92 Jung C., Yabe J. T. and Shea T. B. (2000) C-terminal phosphorylation of the high molecular weight neurofilament subunit correlates with decreased neurofilament axonal transport velocity. Brain Res. 856: 12-19

93 Yabe J. T., Chylinski T., Wang F. S., Pimenta A., Kattar S. D. Linsley M. D. et al. (2001) Neurofilaments consist of distinct populations that can be distinguished by C-terminal phosphorylation, bundling and axonal transport rate in growing axonal neurites. J. Neurosci. 21: 2195-2205

94 Ackerley S., Thornhill P., Grierson A. J., Brownlees J., Anderton B. H., Leigh P. N. et al. (2003) Neurofilament heavy chain side arm phosphorylation regulates axonal transport of neurofilaments. J. Cell Biol. 161: 489-495

95 Ackerley S., Grierson A. J., Brownlees J., Thornhill P., Anderton B. H., Leigh P. N. et al. (2000) Glutamate slows axonal transport of neurofilaments in transfected neurons. J. Cell Biol. 150: 165-176
96 Shea T. B., Jung C. and Pant H. C. (2003) Does neurofilament phosphorylation regulate axonal transport? Trends Neurosci. 26: $397-400$

97 Hart G. W., Haltiwanger R. S., Holt G. D. and Kelly W. G. (1989) Glycosylation in the nucleus and cytoplasm. Annu. Rev. Biochem. 58: 841-874

98 Torres C. R. and Hart G. W. (1984) Topography and polypeptide distribution of terminal $\mathrm{N}$-acetylglucosamine residues on the surfaces of intact lymphocytes. Evidence for O-linked GlcNAc. J. Biol. Chem. 259: 3308-3317

99 Holt G. D. and Hart G. W. (1986) The subcellular distribution of terminal N-acetylglucosamine moieties. Localization of a novel protein-saccharide linkage, O-linked GlcNAc. J. Biol. Chem. 261: 8049-8057

100 Kearse K. P. and Hart G. W. (1991) Lymphocyte activation induces rapid changes in nuclear and cytoplasmic glycoproteins. Proc. Natl. Acad. Sci. USA 88: 1701-1705

101 Haltiwanger R. S., Blomberg M. A. and Hart G. W. (1992) Glycosylation of nuclear and cytoplasmic proteins. Purification and characterization of a uridine diphospho-N-acetylglucosamine:polypeptide beta-N-acetylglucosaminyltransferase. J. Biol. Chem. 267: 9005-9013

102 Haltiwanger R. S., Kelly W. G., Roquemore E. P., Blomberg M. A., Dong L. Y., Kreppel L. et al. (1992) Glycosylation of nuclear and cytoplasmic proteins is ubiquitous and dynamic. Biochem. Soc. Trans. 20: 264-269

103 Chou C. F., Smith A. J. and Omary M. B. (1992) Characterization and dynamics of O-linked glycosylation of human cytokeratin 8 and 18. J. Biol. Chem. 267: 3901-3906

104 Chou S. M., Wang H. S., Taniguchi A. and Bucala R. (1998) Advanced glycation endproducts in neurofilament conglomeration of motoneurons in familial and sporadic amyotrophic lateral sclerosis. Mol. Med. 4: 324-332

105 Hart G. W., Kelly W. G., Blomberg M. A., Roquemore E. P., Dong D. L.-Y., Kreppel L. et al. (1993) Colloq. Ges. Biol. Chem. Mosbach 44: 91-103

106 Hart G. W., Greis K. D., Dong L.-Y. D., Blomberg M. A., Chou T.-Y., Jiang M.-S. et al. (1995) Pure Appl. Chem. 67: 16371645

107 Dong D. L., Xu Z. S., Hart G. W. and Cleveland D. W. (1996) Cytoplasmic O-GlcNAc modification of the head domain and the KSP repeat motif of the neurofilament protein neurofilament-H. J. Biol. Chem. 271: 20845-20852

108 Gill S. R., Wong P. C., Monteiro M. J. and Cleveland D. W. (1990) Assembly properties of dominant and recessive mutations in the small mouse neurofilament (NF-L) subunit. J. Cell Biol. 111: 2005-2019

109 Wong P. C. and Cleveland D. W. (1990) Characterization of dominant and recessive assembly-defective mutations in mouse neurofilament NF-M. J. Cell Biol. 111: 19872003

110 Chin S. S., Macioce P. and Liem R. K. (1991) Effects of truncated neurofilament proteins on the endogenous intermediate filaments in transfected fibroblasts. J. Cell Sci. 99: $335-350$

111 Nixon R. A. (1993) The regulation of neurofilament protein dynamics by phosphorylation: clues to neurofibrillary pathobiology. Brain Pathol. 3: 29-38

112 Xu Z., Dong D. L. and Cleveland D.W. (1994) Neuronal intermediate filaments: new progress on an old subject. Curr. Opin. Neurobiol. 4: 655-661

113 Dong D. L. and Hart G. W. (1994) Purification and characterization of an O-GlcNAc selective N-acetyl-beta-D-glucosaminidase from rat spleen cytosol. J. Biol. Chem. 269: 1932119330

114 Cleveland D. W. and Xu Z. (1995) Neurofilaments and motor neuron disease. In: Alzheimer's Disease: Lessons from Cell Biology, pp. 180-192, Kosik K. S., Christen Y. and Selkoe D. J. (eds), Springer, Berlin 
115 Hoffman P. N. and Lasek R. J. (1975) The slow component of axonal transport: Identification of major structural polypeptides of the axon and their generality among mammalian neurons. J. Cell Biol. 66: 35 1-366

116 Lasek R. J. and Black M. M. (1977) How do axons stop growing? Some clues from the metabolism of the proteins in the slow component of axonal transport. In: Mechanisms, Regulation and Special Functions of Protein Synthesis in Brain, pp. 161-169, Roberts S., Lajtha A. and Gispen W. H. (eds), Elsevier, New York

117 Lasek R. J. and Hoffman P. N. (1976) The neuronal cytoskeleton, axonal transport and axonal growth. Cold Spring Harbor Conf. Cell Prolif. 3: 1021-1049

118 Roots B. I. (1983) Neurofilament accumulation induced in synapses by leupeptin. Science 221: 971-972

119 Gong C. X., Wang J. Z., Iqbal K. and Grundke-Iqbal I. (2003) Inhibition of protein phosphatase $2 \mathrm{~A}$ induces phosphorylation and accumulation of neurofilaments in metabolically active rat brain slices. Neurosci. Lett. 340: 107-110

120 Paggi P. and Lasek R. J. (1987) Axonal transport of cytoskeletal proteins in oculomotor axons and their residence times in the axon terminals. J. Neurosci. 7: 2397-2411

121 Pant H. C. and Gainer H. (1980) Properties of a calciumactivated protease in squid axoplasm which selectively degrades neurofilament proteins. J. Neurobiol. 11: 1-12

122 Buki A., Siman R., Trojanowski J. Q. and Povlishock J. T. (1999) The role of calpain-mediated spectrin proteolysis in traumatically induced axonal injury. J. Neuropathol. Exp. Neurol. 58: 365-375

123 Kampfl A., Posmantur R. M., Zhao X., Schmutzhard E., Clifton G. L. and Hayes R. L. (1997) Mechanisms of calpain proteolysis following traumatic brain injury: implications for pathology and therapy: a review and update. J. Neurotrauma 14: $121-134$

124 Grant P. and Pant H. C. (2000) Neurofilament protein synthesis and phosphorylation. J. Neurocytol. 29: 843-872

125 Sotelo-Silveira J. R., Calliari A., Kun A., Benech J. C., Sanguinetti C., Chalar C. et al. (2000) Neurofilament mRNAs are present and translated in the normal and severed sciatic nerve. J. Neurosci. Res. 62: 65-74

126 Ohara O., Gahara Y., Miyake T., Teraoka H. and Kitamura T. (1993) Neurofilament deficiency in quail caused by nonsense mutation in neurofilament-L gene. J. Cell Biol. 121: 387-395

127 Sakaguchi T., Okada M., Kitamura T. and Kawasaki K. (1993) Reduced diameter and conduction velocity of myelinated fibers in the sciatic nerve of a neurofilament-deficient mutant quail. Neurosci. Lett. 153: 65-68

128 Zhao J. X., Ohnishi A., Itakura C., Mizutani M., Yamamoto T., Hayashi H. et al. (1994) Greater number of microtubules per axon of unmyelinated fibers of mutant quails deficient in neurofilaments: possible compensation for the absence of neurofilaments. Acta Neuropathol. 87: 332-336

129 Eyer J. and Peterson A. (1994) Neurofilament-deficient axons and perikaryal aggregates in viable transgenic mice expressing a neurofilament-betagalactosidase fusion protein. Neuron 12: $389-405$

130 Hirano A., Donnenfeld H., Sasaki S. and Nakano I. (1984) Fine structural observations of neurofilamentous changes in amyotrophic lateral sclerosis. J. Neuropathol. Exp. Neurol. 43: $461-470$

131 Watson D. F., Nachtman F. N., Kuncl R. W. and Griffin J. W. (1994) Altered neurofilament phosphorylation and beta tubulin isotypes in Charcot-Marie-Tooth disease type 1. Neurology 44: 2383-2387

132 Mori H., Oda M. and Mizuno Y. (1996) Cortical ballooned neurons in progressive supranuclear palsy. Neurosci. Lett. 209: $109-112$

133 Schmidt M. L., Martin J. A., Lee V. M. Y. and Trojanowski J. Q. (1996) Convergence of Lewy bodies and neurofibrillary tangles in amygdala neurons of Alzheimer's disease and Lewy body disorders. Acta Neuropathol. 91: 475-481

134 Schmidt R. E., Beaudet L. N., Plurad S. B. and Dorsey D. A. (1997) Axonal cytoskeletal pathology in aged and diabetic human sympathetic autonomic ganglia. Brain Res. 769: 375-383

135 Bomont P., Cavalier L., Blondeau F., Ben Hamida C., Belal S., Tazir M. et al. (2000) The gene encoding gigaxonin, a new member of the cytoskeletal BTB/kelch repeat family, is mutated in giant axonal neuropathy. Nat. Genet. 26: 370-374

136 Shepherd C. E., McCann H., Thiel E. and Halliday G. M. (2002) Neurofilament-immunoreactive neurons in Alzheimer's disease and dementia with Lewy bodies. Neurobiol. Dis. 9: 249-257

137 Xu Z., Cork L. C., Griffin J. W. and Cleveland D. W. (1993) Increased expression of neurofilament subunit NF-L produces morphological alterations that resemble the pathology of human motor neuron disease. Cell 73: 23-33

138 Wong P. C., Marszalek J., Crawford T. O., Xu Z., Hsieh S. T., Griffin J. W. et al. (1995) Increasing neurofilament subunit NF-M expression reduces axonal NF-H, inhibits radial growth, and results in neurofilamentous accumulation in motor neurons. J. Cell Biol. 130: 1413-1422

139 Marszalek J. R., Williamson T. L., Lee M. K., Xu Z., Hoffman P. N., Becher M. W. et al. (1996) Neurofilament subunit NF-H modulates axonal diameter by selectively slowing neurofilament transport. J. Cell Biol. 135: 711-724

140 Kong J., Tung V. W., Aghajanian J. and Xu Z. (1998) Antagonistic roles of neurofilament subunits NF-H and NF-M against NF-L in shaping dendritic arborization in spinal motor neurons. J. Cell Biol. 140: 1167-1176

141 Ma D. M., Descarries L., Micheva K. D., Lepage Y., Julien J. P. and Doucet G. (1999) Severe neuronal losses with age in the parietal cortex and ventrobasal thalamus of mice transgenic for the human NF-L neurofilament protein. J. Comp. Neurol. 406: $433-448$

142 Sanelli T. R., Sopper M. M. and Strong M. J. (2004) Sequestration of nNOS in neurofilamentous aggregate bearing neurons in vitro leads to enhanced NMDA-mediated calcium influx. Brain Res. 1004: 8-17

143 Couillard-Despres S., Zhu Q., Wong P. C., Price D. L., Cleveland D. W. and Julien J. P. (1998) Protective effect of neurofilament heavy gene overexpression in motor neuron disease induced by mutant superoxide dismutase. Proc. Natl. Acad. Sci. USA 95: 9626-9630

144 Beaulieu J. M. and Julien J. P. (2003) Peripherin-mediated death of motor neurons rescued by overexpression of neurofilament NF-H proteins. J. Neurochem. 85: 248-256

145 Williamson T. L., Bruijn L. I., Zhu Q., Anderson K. L., Anderson S. D., Julien J. P. et al. (1998) Absence of neurofilaments reduces the selective vulnerability of motor neurons and slows disease caused by a familial amyotrophic lateral sclerosis-linked superoxide dismutase 1 mutant. Proc. Natl. Acad. Sci. USA 95: 9631-9636

146 Nguyen M. D., Lariviere R. C. and Julien J. P. (2000) Reduction of axonal caliber does not alleviate motor neuron disease caused by mutant superoxide dismutase 1 . Proc. Natl. Acad. Sci. USA 97: 12306-12311

147 Nguyen M. D., Lariviere R. C. and Julien J. P. (2001) Deregulation of $\mathrm{Cdk} 5$ in a mouse model of ALS: toxicity alleviated by perikaryal neurofilament inclusions. Neuron 30: 135-147

148 Nguyen M. D., Boudreau M., Kriz J., Couillard-Despres S., Kaplan D. R. and Julien J. P. (2003) Cell cycle regulators in the neuronal death pathway of amyotrophic lateral sclerosis caused by mutant superoxide dismutase 1. J. Neurosci. 23: $2131-2140$

149 Smith M. A., Rudnicka-Nawrot M., Richey P. L., Praprotnik D., Mulvihill P., Miller C. A. et al. (1995) Carbonyl-related posttranslational modification of neurofilament protein in the neurofibrillary pathology of Alzheimer's disease. J. Neurochem. 64: 2660-2666 
150 Sayre L. M., Sha W., Xu G., Kaur K., Nadkarni D., Subbanagounder G. et al. (1996). Immunochemical evidence supporting 2-pentylpyrrole formation on proteins exposed to 4-hydroxy-2-nonenal. Chem. Res. Toxicol. 9: 1194-1201

151 Wataya T., Nunomura A., Smith M. A., Siedlak S. L., Harris P. L., Shimohama S. et al. (2002) High molecular weight neurofilament proteins are physiological substrates of adduction by the lipid peroxidation product hydroxynonenal. J. Biol. Chem. 277: 4644-4648

152 Liu Q., Raina A. K., Smith M. A., Sayre L. M. and Perry G. (2003) Hydroxynonenal, toxic carbonyls, and Alzheimer disease. Mol. Aspects Med. 24: 305-313

153 Veeranna, Amin N. D., Ahn N. G., Jaffe H., Winters C. A., Grant P. et al. (1998) Mitogen-activated protein kinases $($ Erk1,2) phosphorylate Lys-Ser-Pro (KSP) repeats in neurofilament proteins NF-H and NF-M. J. Neurosci. 18: 40084021

154 de Waegh S. and Brady S. T. (1990) Altered slow axonal transport and regeneration in a myelin-deficient mutant mouse: the trembler as an in vivo model for Schwann cell-axon interactions. J. Neurosci. 10: 1855-1865

155 Leski M. L., Bao F., Wu L., Qian H., Sun D. and Liu D. (2001) Protein and DNA oxidation in spinal injury: neurofilaments an oxidation target. Free Radic. Biol. Med. 30: 613-624

156 Yamasaki H., Itakura C., and Mizutani M. (1991) Hereditary hypotrophic axonopathy with neurofilament deficiency in a mutant strain of the Japanese quail. Acta Neuropathol. 82: 427-434

157 Julien J. P. (1999) Neurofilament functions in health and disease. Curr. Opin. Neurobiol. 9: 554-560

158 Levavasseur F., Zhu Q. and Julien J. P. (1999) No requirement of $\alpha$-internexin for nervous system development and for radial growth of axons. Mol. Brain Res. 69: 104-112

159 Friede R. and Sarnorajski T. (1970) Axon caliber related to neurofilaments and microtubules in sciatic nerve. Anat. Rec. 167: 379-388

160 Hoffman P. N., Griffin J. W. and Price D. L. (1984) Control of axonal caliber by neurofilament transport. J. Cell Biol. 99: $705-714$

161 Tu, P.-H., Elder G., Lazzarini R. A., Nelson D., Trojanowski J. Q. and Lee V. M.-Y. (1995) Overexpression of the human NFM subunit in transgenic mice modifies the level of endogenous NFL and the phosphorylation state of NFH subunits. J. Cell Biol. 129: 1629-1640

162 Gama Sosa M. A., Friedrich V. L. Jr, DeGasperi R., Kelley K., Wen P. H., Senturk E. et al. (2003) Human midsized neurofilament subunit induces motor neuron disease in transgenic mice. Exp. Neurol. 184: 408-419

163 Lee M. K., Marszalek J. R. and Cleveland D. W. (1994) A mutant neurofilament subunit causes massive, selective motor neuron death: implications for the pathogenesis of human motor neuron disease. Neuron 13: 975-988

164 Julien J. P., Tretjakoff I., Beaudet L. and Peterson A. (1987) Expression and assembly of a human neurofilament protein in transgenic mice provide a novel neuronal marking system. Genes Dev. 1: 1085-1095

165 Cote F., Collard J. F. and Julien J. P. (1993) Progressive neuronopathy in transgenic mice expressing the human neurofilament heavy gene: a mouse model of amyotrophic lateral sclerosis. Cell 73: 35-46

166 Collard J. F. and Julien J. P. (1995) A simple test to monitor the motor dysfunction in a transgenic mouse model of amyotrophic lateral sclerosis. J. Psychiatry Neurosci. 20: $80-86$

167 Meier J., Couillard-Despres S., Jacomy H., Gravel C. and Julien J. P. (1999) Extra neurofilament NF-L subunits rescue motor neuron disease caused by overexpression of the human NF-H gene in mice. J. Neuropathol. Exp. Neurol. 58: 1099- 1110

168 Ahlijanian M. K., Barrezueta N. X., Williams R. D., Jakowski A., Kowsz K. P., McCarthy S. et al. (2000) Hyperphosphory- lated tau and neurofilament and cytoskeletal disruptions in mice overexpressing human $\mathrm{p} 25$, an activator of cdk5. Proc. Natl. Acad. Sci. USA 97: 2910-2915

169 Carpenter S. (1968) Proximal axonal enlargement in motor neuron disease. Neurology 18: 841-851

170 Averback P. (1981) Unusual particles in motor neuron disease. Arch. Pathol. Lab. Med. 105: 490-493

171 Delisle M. B. and Carpenter S. (1984) Neurofibrillary axonal swellings and amyotrophic lateral sclerosis. J. Neurol. Sci. 63: $241-250$

172 Munoz D. G., Greene C., Perl D. P. and Selkoe D. J. (1988) Accumulation of phosphorylated neurofilaments in anterior horn motoneurons of amyotrophic lateral sclerosis patients. J. Neuropathol. Exp. Neurol. 47: 9-18

173 Leigh P. N., Dodson A., Swash M., Brion J. P. and Anderton B. H. (1989) Cytoskeletal abnormalities in motor neuron disease. An immunocytochemical study. Brain 112: 521-535

174 Murayama S., Bouldin T. W. and Suzuki K. (1992) Immunocytochemical and ultrastructural studies of upper motor neurons in amyotrophic lateral sclerosis. Acta Neuropathol. 83: $518-524$

175 Julien J. P., Cote F. and Collard J. F. (1995) Mice overexpressing the human neurofilament heavy gene as a model of ALS. Neurobiol. Aging 16: 487-492

176 McLachlan D. R., Lukiw W. J., Wong L., Bergeron C. and Bech-Hansen N. T. (1988) Selective messenger RNA reduction in Alzheimer's disease. Brain Res. 427: 255-261

177 Bergeron C., Beric-Maskarel K., Muntasser S., Weyer L., Somerville M. J. and Percy M. E. (1994) Neurofilament light and polyadenylated mRNA levels are decreased in amyotrophic lateral sclerosis motor neurons. J. Neuropathol. Exp. Neurol. 53: 221-230

178 Wong N. K., He B. P. and Strong M. J. (2000) Characterization of neuronal intermediate filament protein expression in cervical spinal motor neurons in sporadic amyotrophic lateral sclerosis (ALS). J. Neuropathol. Exp. Neurol. 59: 972-982

179 Menzies F. M., Grierson A. J., Cookson M. R., Heath P. R., Tomkins J., Figlewicz D. A. et al. (2002) Selective loss of neurofilament expression in $\mathrm{Cu} / \mathrm{Zn}$ superoxide dismutase (SOD1) linked amyotrophic lateral sclerosis. J. Neurochem. 82: $1118-1128$

180 Figlewicz D. A., Krizus A., Martinoli M. G., Meininger V., Dib M., Rouleau G. A. et al. (1994) Variants of the heavy neurofilament subunit are associated with the development of amyotrophic lateral sclerosis. Hum. Mol. Genet. 3: 1757-1761

181 Tomkins J., Usher P., Slade J. Y., Ince P. G., Curtis A., Bushby K. et al. (1998) Novel insertion in the KSP region of the neurofilament heavy gene in amyotrophic lateral sclerosis (ALS). Neuroreport 9: 3967-3970

182 Al-Chalabi A., Andersen P. M., Nilsson P., Chioza B., Andersson J. L., Russ C. et al. (1999) Deletions of the heavy neurofilament subunit tail in amyotrophic lateral sclerosis. Hum. Mol. Genet. 8: 157-164

183 Mayeux R., Honig L. S., Tang M. X., Manly J., Stern Y., Schupf N. et al. (2003) Plasma A[beta]40 and A[beta]42 and Alzheimer's disease: relation to age, mortality, and risk. Neurology 61: 1185-1190

184 Seshadri S., Wolf P. A., Beiser A., Au R., McNulty K., White R. et al. (1997) Lifetime risk of dementia and Alzheimer's disease. The impact of mortality on risk estimates in the Framingham Study. Neurology 49: 1498-1504

185 Selkoe D. J. (2000) Toward a comprehensive theory for Alzheimer's disease. Hypothesis: Alzheimer's disease is caused by the cerebral accumulation and cytotoxicity of amyloid betaprotein. Ann. N. Y. Acad. Sci. 924: 17-25

186 Lee V. M., Goedert M. and Trojanowski J. Q. (2001) Neurodegenerative tauopathies. Annu. Rev. Neurosci. 24: 1121-1159

187 McGeer P. L. and McGeer E. G. (2001) Inflammation, autotoxicity and Alzheimer disease. Neurobiol. Aging 22: 799-809 
188 Weiner H. L. and Selkoe D. J. (2002) Inflammation and therapeutic vaccination in CNS diseases. Nature 420: 879-884

189 Markesbery W. R. (1997) Oxidative stress hypothesis in Alzheimer's disease. Free Radic. Biol. Med. 23: 134-147

190 Perry G., Castellani R. J., Hirai K. and Smith M. A. (1998) Reactive oxygen species mediate cellular damage in Alzheimer disease. J. Alzheimers Dis. 1: 45-55

191 Perry G., Nunomura A., Hirai K., Zhu X., Perez M., Avila J. et al. (2002) Is oxidative damage the fundamental pathogenic mechanism of Alzheimer's and other neurodegenerative diseases? Free Radic. Biol. Med. 33: 1475-1479

192 Christen Y. (2000) Oxidative stress and Alzheimer disease. Am. J. Clin. Nutr. 71: 621S-629S

193 Picklo M. J., Montine T. J., Amarnath V. and Neely M. D. (2002) Carbonyl toxicology and Alzheimer's disease. Toxicol. Appl. Pharmacol. 184: 187-197

194 Nunomura A., Perry G., Aliev G., Hirai K., Takeda A., Balraj E. K. et al. (2001) Oxidative damage is the earliest event in Alzheimer disease. J. Neuropathol. Exp. Neurol. 60: 759767

195 Gong C. X., Lidsky T., Wegiel J., Zuck L., Grundke-Iqbal I. and Iqbal K. (2000) Phosphorylation of microtubule-associated protein tau is regulated by protein phosphatase $2 \mathrm{~A}$ in mammalian brain. Implications for neurofibrillary degeneration in Alzheimer's disease. J. Biol. Chem. 275: 5535-5544

196 Trojanowski J. Q., Mawal-Dewan M., Schmidt M. L., Martin J. and Lee V. M. (1993) Localization of the mitogen activated protein kinase ERK2 in Alzheimer's disease neurofibrillary tangles and senile plaque neurites. Brain Res. 618: 333-337

197 Mandelkow E. M., Drewes G., Biernat J., Gustke N., Van Lint J., Vandenheede J. R. et al. (1992) Glycogen synthase kinase-3 and the Alzheimer-like state of microtubule-associated protein tau. FEBS Lett. 314: 315-321

198 Lew J., Huang Q. Q., Qi Z., Winkfein R. J., Aebersold R., Hunt T. et al. (1994) A brain-specific activator of cyclindependent kinase 5. Nature 371: 423-426

199 Maccioni R. B., Otth C., Concha I. I. and Munoz J. P. (2001) The protein kinase Cdk5. Structural aspects, roles in neurogenesis and involvement in Alzheimer's pathology. Eur. J. Biochem. 268: 1518-1527

200 Hely M. A., Morris J. G., Traficante R., Reid W. G., O'Sullivan D. J. and Williamson P. M. (1999) The sydney multicentre study of Parkinson's disease: progression and mortality at 10 years. J. Neurol. Neurosurg. Psychiatry 67: 300-307

201 Galloway P. G., Mulvihill P. and Perry G. (1992) Filaments of Lewy bodies contain insoluble cytoskeletal elements. Am. J. Pathol. 140: 809-822

202 Trimmer P. A., Borland M. K., Keeney P. M., Bennett J. P. Jr and Parker W. D. Jr (2004) Parkinson's disease transgenic mitochondrial cybrids generate Lewy inclusion bodies. J. Neurochem. 88: 800-812

203 Leroy E., Anastasopoulos D., Konitsiotis S., Lavedan C. and Polymeropoulos M. H. (1998) Deletions in the Parkin gene and genetic heterogeneity in a Greek family with early onset Parkinson's disease. Hum. Genet. 103: 424-427
204 Abbas N., Lucking C. B., Ricard S., Durr A., Bonifati V., De Michele G. et al. (1999) A wide variety of mutations in the parkin gene are responsible for autosomal recessive parkinsonism in Europe. French Parkinson's Disease Genetics Study Group and the European Consortium on Genetic Susceptibility in Parkinson's Disease. Hum. Mol. Genet. 8: 567-574

205 Lucking C. B., Durr A., Bonifati V., Vaughan J., De Michele G., Gasser T. et al. (2000) Association between early-onset Parkinson's disease and mutations in the parkin gene. French Parkinson's Disease Genetics Study Group. N. Engl. J. Med. 342: $1560-1567$

206 Lim K. L., Dawson V. L. and Dawson T. M. (2002) The genetics of Parkinson's disease. Curr. Neurol. Neurosci. Rep. 2: 439-446

207 Lavedan C., Buchholtz S., Nussbaum R. L., Albin R. L. and Polymeropoulos M. H. (2002) A mutation in the human neurofilament M gene in Parkinson's disease that suggests a role for the cytoskeleton in neuronal degeneration. Neurosci. Lett. 322: $57-61$

208 Hill W. D., Arai M., Cohen J. A. and Trojanowski J. Q. (1993) Neurofilament mRNA is reduced in Parkinson's disease substantia nigra pars compacta neurons. J. Comp. Neurol. 329: $328-336$

209 Mersiyanova I. V., Perepelov A. V., Polyakov A. V., Sitnikov V. F., Dadali E. L., Oparin R. B. et al. (2000) A new variant of Charcot-Marie- Tooth disease type 2 is probably the result of a mutation in the neurofilament-light gene. Am. J. Human Genet. 67: 37-46

210 De Jonghe P., Mersivanova I., Nelis E., Del Favero J., Martin J. J., Van Broeckhoven C. et al. (2001) Further evidence that neurofilament light chain gene mutations can cause CharcotMarie-Tooth disease type 2E. Ann. Neurol. 49: 245-249

211 Georgiou D. M., Zidar J., Korosec M., Middleton L. T., Kyriakides T. and Christodoulou K. (2002) A novel NF-L mutation Pro22Ser is associated with CMT2 in a large Slovenian family. Neurogenetics 4: 93-96

212 Jordanova A., De Jonghe P., Boerkoel C. F., Takashima H., De Vriendt E., Ceuterick C. et al. (2003) Mutations in the neurofilament light chain gene (NEFL) cause early onset severe Charcot-Marie-Tooth disease. Brain 126: 590-597

213 Yoshihara T., Yamamoto M., Hattori N., Misu K., Mori K., Koike H. et al. (2002) Identification of novel sequence variants in the neurofilament-light gene in a Japanese population: analysis of Charcot-Marie-Tooth disease patients and normal individuals. J. Peripher. Nerv. Syst. 7: 221-224

214 Fernyhough P., Gallagher A., Averill S. A., Priestley J. V., Hounsom L., Patel J. et al. (1999) Aberrant neurofilament phosphorylation in sensory neurons of rats with diabetic neuropathy. Diabetes 48: $881-889$

215 McLean W. G. (1997) The role of axonal cytoskeleton in diabetic neuropathy. Neurochem. Res. 22: 951-956

216 Caughey B. and Lansbury, P. T. Jr (2003) Protofibrils, pores, fibrils, and neurodegeneration: separating the responsible protein aggregates from the innocent bystanders. Annu. Rev. Neurosci. 26: 267-298 